\title{
Diazotrophic Trichodesmium impact on UV-Vis radiance and pigment composition in the western tropical South Pacific
}

\author{
Cécile Dupouy $^{1,2}$, Robert Frouin ${ }^{3}$, Marc Tedetti ${ }^{1}$, Morgane Maillard $^{1}$, Martine Rodier $^{4}$, Fabien Lombard $^{5}$, \\ Lionel Guidi $^{5}$, Marc Picheral ${ }^{5}$, Jacques Neveux ${ }^{6}$, Solange Duhamel ${ }^{7}$, Bruno Charrière ${ }^{8}$, and Richard Sempéré ${ }^{1}$ \\ ${ }^{1}$ Aix Marseille Univ., Université de Toulon, CNRS, IRD, MIO UM 110, 13288, Marseille, France \\ ${ }^{2}$ MIO UM 110, Centre IRD de Noumea, 98848 Nouméa, New Caledonia \\ ${ }^{3}$ Scripps Institution of Oceanography, University of California San Diego, La Jolla, CA 92093-0224, USA \\ ${ }^{4}$ EIO (Ecosystèmes Insulaires Océaniens), Institut de Recherche pour le Développement-Université de la Polynésie \\ Française-Institut Malarmé-Ifremer, Papeete, French Polynesia \\ ${ }^{5}$ Sorbonne Universités, UPMC Université Paris 06, CNRS, Laboratoire d'Océanographie de Villefranche (LOV), \\ Observatoire Océanologique, 06230 Villefranche-sur-Mer, France \\ ${ }^{6}$ Sorbonne Universités, UPMC Univ Paris 06, CNRS, Laboratoire d'Océanographie Microbienne (LOMIC), Observatoire \\ Océanologique, 66650 Banyuls-sur-Mer, France \\ ${ }^{7}$ Lamont-Doherty Earth Observatory, Columbia University, Palisades, New York, USA \\ ${ }^{8}$ Centre de Formation et de Recherche sur les Environnements Méditerranéens (CEFREM, UMR CNRS UPVD 5110), 52 \\ Avenue Paul Alduy, 66860 Perpignan CEDEX, France
}

Correspondence: Cécile Dupouy (cecile.dupouy@ird.fr)

Received: 31 December 2017 - Discussion started: 15 January 2018

Revised: 25 June 2018 - Accepted: 10 July 2018 - Published: 30 August 2018

\begin{abstract}
We assessed the influence of the marine diazotrophic cyanobacterium Trichodesmium on the bio-optical properties of western tropical South Pacific (WTSP) waters $\left(18-22^{\circ} \mathrm{S}, 160^{\circ} \mathrm{E}-160^{\circ} \mathrm{W}\right)$ during the February-March 2015 OUTPACE cruise. We performed measurements of backscattering and absorption coefficients, irradiance, and radiance in the euphotic zone with a Satlantic MicroPro free-fall profiler and took Underwater Vision Profiler 5 (UPV5) pictures for counting the largest Trichodesmium spp. colonies. Pigment concentrations were determined by fluorimetry and high-performance liquid chromatography and picoplankton abundance by flow cytometry. Trichome concentration was estimated from pigment algorithms and validated by surface visual counts. The abundance of large colonies counted by the UVP5 (maximum 7093 colonies $\mathrm{m}^{-3}$ ) was well correlated to the trichome concentrations (maximum 2093 trichomes $\mathrm{L}^{-1}$ ) with an aggregation factor of 600 . In the Melanesian archipelago, a maximum of 4715 trichomes $\mathrm{L}^{-1}$ was enumerated in pump samples $(3.2 \mathrm{~m})$ at $20^{\circ} \mathrm{S}, 16730^{\circ} \mathrm{E}$. High Trichodesmium abundance was always associated with absorption peaks of
\end{abstract}

mycosporine-like amino acids $(330,360 \mathrm{~nm})$ and high particulate backscattering, but not with high Chl $a$ fluorescence or blue particulate absorption $(440 \mathrm{~nm})$. Along the west-toeast transect, Trichodesmium together with Prochlorococcus represented the major part of total chlorophyll concentration; the contribution of other groups were relatively small or negligible. The Trichodesmium contribution to total chlorophyll concentration was the highest in the Melanesian archipelago around New Caledonia and Vanuatu (60\%), progressively decreased to the vicinity of the islands of Fiji $(30 \%)$, and reached a minimum in the South Pacific Gyre where Prochlorococcus dominated chlorophyll concentration. The contribution of Trichodesmium to zeaxanthin was respectively 50, 40 and $20 \%$ for these regions. During the OUTPACE cruise, the relationship between normalized water-leaving radiance $\left(\mathrm{nL}_{\mathrm{w}}\right)$ in the ultraviolet and visible and chlorophyll concentration was similar to that found during the BIOSOPE cruise in the eastern tropical Pacific. Principal component analysis (PCA) of OUTPACE data showed that $\mathrm{nL}_{\mathrm{w}}$ at $305,325,340,380,412$ and $440 \mathrm{~nm}$ was strongly correlated to chlorophyll and zeaxanthin, while $\mathrm{nL}_{\mathrm{w}}$ at 490 
and $565 \mathrm{~nm}$ exhibited lower correlations. These results, as well as differences in the PCA of BIOSOPE data, indicated that $\mathrm{nL}_{\mathrm{w}}$ variability in the greenish blue and yellowish green during OUTPACE was influenced by other variables associated with Trichodesmium presence, such as backscattering coefficient, phycoerythrin fluorescence and/or zeaxanthin absorption, suggesting that Trichodesmium detection should involve examination of $\mathrm{nL}_{\mathrm{w}}$ in this spectral domain.

\section{Introduction}

The ecological importance of filamentous diazotrophs (Trichodesmium spp. in particular) in the archipelago region of the western tropical South Pacific (WTSP) has been suspected for a long time (Dandonneau and Gohin, 1984; Dupouy et al., 1988, 1990, 1992). Trichodesmium spp. have to be taken into account for estimating the global oceanic nitrogen and carbon fluxes (Capone et al., 1997; Bonnet et al., 2017; Dutheil et al., 2018; Shiosaki et al., 2014). In the past decade, efforts have been made to extract abundances of different autotrophic groups from ocean color data (Blondeau-Patissier et al., 2014; Bracher et al., 2017). Other attempts have been made to get remote sensing estimates of the abundance and diazotroph activity of Trichodesmium at a global scale (Subramaniam et al., 2002; Westberry et al., 2005, 2006; McKinna et al., 2011; Dupouy et al., 2011; McKinna, 2015). Satellite detection of Trichodesmium is facilitated when concentration at the sea surface is high, leading to a building of mat larger than a $300 \mathrm{~m}$ satellite pixel as these mats induce a high reflectance in the near infrared, a "red edge", which can easily be observed (Hu et al., 2010; Dupouy et al., 2011; McKinna et al., 2011; Gower et al., 2014; McKinna, 2015; Rousset et al., 2018). Detection becomes more difficult when Trichodesmium concentrations are at non-bloom or sub-bloom abundance, i.e., when colonies are distributed throughout the water column and mixed with other species. Using an empirical statistical approach, De Boissieu et al. (2014) determined that at sufficient concentration level, these filamentous diazotrophs could be distinguished from other groups. This complements empirical parameterizations that were used to derive the vertical distribution of different phytoplankton groups (micro-, nano- and picoplankton) using high-performance liquid chromatography (HPLC) diagnostic pigments and surface chlorophyll $a$ concentration ( $\mathrm{Chl} a$ ) determined from space (Uitz et al., 2006; Ras et al., 2008; Brewin et al., 2011).

In order to validate Trichodesmium discrimination algorithms, and to improve the knowledge of the influence of Trichodesmium spp. on apparent (AOPs) and inherent (IOPs) optical properties of seawater, accurate field determinations of these properties are required. Among AOPs, normalized water-leaving radiance $\mathrm{nL}_{\mathrm{w}}(\lambda)\left(\mathrm{in} \mu \mathrm{W} \mathrm{cm}{ }^{-2} \mathrm{sr}^{-1}\right)$, the radiance that emerges from the ocean in the absence of atmosphere, with the Sun at zenith, at the mean Earth-Sun dis- tance (Gordon, 2005), is governed by two main IOPs (Mobley, 1994; Kirk, 1994): volume absorption $\left(a(\lambda)\right.$ in $\left.\mathrm{m}^{-1}\right)$ and volume backscattering $\left(b_{\mathrm{b}}\right.$ in $\left.\mathrm{m}^{-1}\right)$ coefficients. IOPs are controlled by the concentrations of optically active components in a volume of water, which include phytoplankton and colored detrital matter (CDM), the latter being composed of non-algal particulate matter (NAP) and chromophoric dissolved organic matter (CDOM). If AOPs are well related to phytoplankton pigments in Case I oceanic waters (Morel and Maritorena, 2001; Morel et al., 2007), this relationship might be modified by the presence of Trichodesmium (with moderate $\mathrm{Chl} a$ concentrations $<1 \mathrm{mg} \mathrm{m}^{-3}$ ). As summarized in Westberry and Siegel (2005), Trichodesmium displays unique optical properties that may allow their detection: (1) a strong absorption in the ultraviolet (UV) domain related to the presence of mycosporine-like amino acids (MAAs) (Subramaniam et al., 1999a; Dupouy et al., 2008), (2) a higher relative reflectance near $570 \mathrm{~nm}$ due to phycoerythrin fluorescence (Borstad et al., 1992; Subramaniam et al., 1999b) and (3) increased backscattering across all wavelengths caused by the change in refraction index of intracellular gas vacuoles (Borstad et al., 1992; Subramaniam et al., 1999b; Dupouy et al., 2008).

The WTSP between New Caledonia and the Tonga Trench is particularly rich in Trichodesmium colonies during summer (Dupouy et al., 1988, 2000, 2011; Biegala et al., 2014), and this richness is further enhanced during the positive phase of the El Niño-Southern Oscillation (ENSO) in 2003 (Tenório et al., 2018). Using bio-optical measurements, this study aims (1) to describe several AOPs and IOPs of interest in the UV and visible domains of WTSP waters, as well as pigments, and abundance of all phytoplanktonic cells including large and smaller Trichodesmium colonies and picoplankton and (2) to determine the influence of Trichodesmium spp. on in situ measurements of ocean color, and absorption and backscattering coefficients. For this purpose, we used the same type of measurements made in the tropical oligotrophic ocean during the BIOSOPE cruise (Tedetti et al., 2007, 2010).

\section{Material and methods}

\subsection{Study area}

The Oligotrophy to the UlTra-oligotrophy PACific Experiment (OUTPACE cruise, 18 February to 3 April 2015) was conducted on board R/V L'Atalante in the WTSP (Table 1, Fig. 1). In situ measurements and water sampling were performed at 15 stations along a $4000 \mathrm{~km}$ transect. This transect extended from the mesotrophic waters of the Melanesian archipelago (MA: SD1 to SD6) near New Caledonia and Vanuatu, to the Fijian archipelago between Fiji and Tonga (FI: SD7 to SD12), and to the eastern end in the hyper-oligotrophic waters of the South Pacific Gyre, east of 
Tonga Trench (SPG: SD13 to SD15). In addition, three longduration stations $\mathrm{A}, \mathrm{B}$ and $\mathrm{C}$ were sampled during 7 days in each of these three regions (LDA in MA, LDB in FI and LDC in SPG; Fig. 1). General biogeochemical and hydrographic characteristics of the waters along this transect are described in Moutin et al. (2017).

\subsection{Radiometric measurements and determination of $\mathrm{nL}_{\mathrm{w}}(\lambda), \mathrm{K}_{\mathbf{d}}(\lambda)$ and $Z 10 \%(\lambda)$ values}

At each station, two or more profiles of downward irradiance $\left(E_{\mathrm{d}}(Z, \lambda)\right.$ in $\left.\mu \mathrm{W} \mathrm{cm}{ }^{-2}\right)$ and upward radiance $\left(L_{\mathrm{u}}(Z, \lambda)\right.$ in $\left.\mu \mathrm{W} \mathrm{cm}{ }^{-2} \mathrm{sr}^{-1}\right)$ were made around solar noon using a Satlantic MicroPro free-fall profiler equipped with OCR-504 downward irradiance and upward radiance sensors with UVB (305 nm), UV-A $(325,340$ and $380 \mathrm{~nm})$ and visible (412, 443, 490 and $565 \mathrm{~nm}$ ) spectral channels, as further described in Tedetti et al. (2010). The MicroPro profiler was operated from the rear of the ship and deployed $30 \mathrm{~m}$ away to minimize the disturbances of the ship. Surface irradiance $\left(E_{\mathrm{s}}(\lambda)\right)$ in $\mu \mathrm{W} \mathrm{cm}{ }^{-2}$ was concomitantly measured at the same wavelengths on the ship deck using other OCR-504 sensors to take into account the short-time variations of cloud conditions during the cast. Surface and in-water radiometers were calibrated before the cruise. Mostly, cloudy sky conditions existed during the profiles (only a few acquisitions were made under clear skies), and at SD5 at 17:30-19:00, they were made under a heavy shower. SD3, SD4 and SD13 profiles were not available (night stations). Details of the casts can be found in Appendix A. For the $\mathrm{nL}_{\mathrm{w}}(\lambda)$ of the longduration stations, an average on 7 days was calculated as representative of the station, with coefficients of variation of $12-14 \%$ at LDA, $6-9 \%$ at LDB (without day 4) and $2.5 \%$ at LDC. Diffuse attenuation coefficient for downward irradiance $\left(\mathrm{K}_{\mathrm{d}}(\lambda)\right.$ in $\left.\mathrm{m}^{-1}\right)$ was determined using $E_{\mathrm{d}}(Z, \lambda)$ and $E_{\mathrm{S}}(\lambda)$ values (Appendix A). The first optical depth corresponding to the surface layer observed by the satellite ocean color instruments (Kirk, 1994) $\left(Z_{10 \%}(\lambda)\right.$ in $\left.m\right)$ was extrapolated from $K_{d}(\lambda)$ and calculated as $\ln (10) / K_{d}(\lambda)$. Determination of $\mathrm{nL}_{\mathrm{w}}(\lambda)$ was conducted from $L_{\mathrm{u}}(Z, \lambda)$ values and diffuse attenuation coefficient for upward radiance $\left(K_{L}(\lambda)\right.$ in $\mathrm{m}^{-1}$ ), within different depths according to stations and wave bands, then normalized by $E_{\mathrm{s}}(\lambda)$ (see calculations in Appendix A). The $K_{\mathrm{d}}(\lambda)$ data presented in this study are average values of two to three upward radiance casts (coefficient of variation $<8 \%$ for each station concerned).

\subsection{Water sampling}

Seawater samples were collected during the noon casts at different depths using 12 L Niskin bottles for the determination of various parameters. For the determination of Chl $a$ and particulate (phytoplankton + NAP) absorption coefficient $\left(a_{P}(\lambda)\right)$, samples were collected at depths corresponding to different percents of PAR (i.e., 75, 54, 36, 10, 1,
$0.1 \%)$ and filtered $(288 \mathrm{~mL}$ for $\mathrm{Chl} a$ determination by fluorometry, and $2.25 \mathrm{~L}$ for $\left.a_{P}(\lambda)\right)$ through $25 \mathrm{~mm}$ Whatman $\mathrm{GF} / \mathrm{F}$ filters. Then, the filters were immediately stored in liquid $\mathrm{N}_{2}\left(-196^{\circ} \mathrm{C}\right)$ in Nunc ${ }^{\circledR}$ cryogenic vials until analysis. Samples were also collected at all depths for liposoluble HPLC pigment analyses (see LOV laboratory data, OUTPACE database, J. Ras). In addition, samples for HPLC pigments were taken in duplicate at surface and deep chlorophyll maximum (DCM) as part of a NASA satellite validation program. For this, 3 to $4.5 \mathrm{~L}$ of seawater was filtered onto $25 \mathrm{~mm}$ Whatman GF/F filters, which were further stored in liquid $\mathrm{N}_{2}$ until analyses at NASA. Water-soluble pigment (phycoerythrin, PE) concentration was determined for the $>10 \mu \mathrm{m}$ size fraction. Therefore $4.5 \mathrm{~L}$ of seawater was filtered onto $47 \mathrm{~mm}$ Nuclepore filters with pore sizes $10 \mu \mathrm{m}$ and stored in liquid $\mathrm{N}_{2}$ in Nunc ${ }^{\circledR}$ cryogenic vials $(\mathrm{PE}>10 \mu \mathrm{m})$. Filters were preserved (at $-80^{\circ} \mathrm{C}$ ) until analysis in the laboratory (IRD French Polynesia).

For the determination of picoplanktonic population abundances (Bock et al., 2018), water samples were fixed with paraformaldehyde (final concentration of $0.2 \%$ ) immediately after sampling, flash frozen in liquid nitrogen, and stored in liquid $\mathrm{N}_{2}$ in Nunc ${ }^{\circledR}$ cryogenic vials until analysis, and abundances at $5 \mathrm{~m}$ were selected for our study. For the determination of CDOM absorption, $200 \mathrm{~mL}$ of seawater was immediately filtered on Micropore filters of $0.2 \mu \mathrm{m}$ pore size using Nalgene filtration units previously rinsed twice with HCL and stored in SCHOTT ${ }^{\circledR}$ glass bottles, previously combusted $\left(450{ }^{\circ} \mathrm{C}, 6 \mathrm{~h}\right)$ and rinsed twice with HCL. Pump samples (depth of $3.5 \mathrm{~m}$ ) were also collected all along three transects in order to increase the frequency of both pigments and IOPs' surface measurements (Chl $a$, HPLC-NASA) in areas characterized by important Trichodesmium surface slicks: the "Simbada" transect, with 7 samples between SD3 and SD4 in the MA, the high-frequency HF1 transect (31 samples) in the MA near LDA, and the high-frequency HF2 transect in the FI near LDB (42 samples). Besides radiometric measurements and water sampling, in situ measurements were also performed for the determination of Trichodesmium spp. colonies and backscattering coefficients (see below).

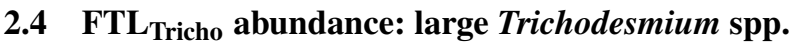 colonies}

The Underwater Vision Profiler 5 (UVP5), serial number Sn003, pixel size ca. $0.147 \mathrm{~mm} \times 0.147 \mathrm{~mm}$ (Picheral et al., 2010) was coupled to the metal structure of the CTD. The device emitted flashes of red LED light that illuminated $0.95 \mathrm{~L}$ of water. Images of all particles within the illuminated area were recorded and analyzed in terms of abundances of defined size ranges. Objects larger than 30 pixels were saved and uploaded on EcoTaxa (http://ecotaxa.obs-vlfr.fr/prj/37, last access: 20 August 2018) and further determined on board as Trichodesmium colonies of fusiform- and roundshaped colonies of all sizes. From 190074 objects recovered, 
Table 1. Main characteristics of the OUTPACE stations for the TChl $a$ concentration, PE $>10 \mu$, FTL Tricho and attenuation coefficients from the free-fall Satlantic UV radiometer. TChl $a$ : average concentrations in total chlorophyll $a$ (monovinyl Chl $a+\operatorname{divinyl~Chl~} a$ ) in surface waters derived from HPLC analyses, based on duplicate analyses $(\mathrm{CV}<8 \%)$. FTL Tricho abundance: determined using underwater vision profiler 5 (UVP5). DCM: deep chlorophyll maximum. PE $>10 \mu \mathrm{m}$ : phycoerythrin $>10 \mu \mathrm{m}$. $K_{\mathrm{d}}$ : diffuse attenuation coefficient for downward irradiance in the UV $(305,325,340,380 \mathrm{~nm})$ and PAR $(400-700 \mathrm{~nm})$ domains. * Values for long-duration stations, i.e., LDA, LDB and LDC, averaged over 7 days. nd: could not be determined (night station).

\begin{tabular}{|c|c|c|c|c|c|c|c|c|c|c|c|c|c|}
\hline \multirow[b]{2}{*}{ Station } & \multirow[b]{2}{*}{ Longitude } & \multirow[b]{2}{*}{ Latitude } & \multirow[b]{2}{*}{ Date } & \multirow[b]{2}{*}{ UT time } & \multirow[b]{2}{*}{$\begin{array}{r}\text { TChl } a \\
\left(\mathrm{mg} \mathrm{m}^{-3}\right)\end{array}$} & \multirow[b]{2}{*}{$\begin{array}{l}\text { FTL }_{\text {Tricho }} \\
\left(\mathrm{Col} \mathrm{m}^{-3}\right)\end{array}$} & \multirow[b]{2}{*}{$\begin{array}{r}\mathrm{DCM} \\
(\mathrm{m})\end{array}$} & \multirow[b]{2}{*}{$\begin{array}{l}\mathrm{PE}>10 \mu \mathrm{m} \\
\quad\left(\mathrm{mg} \mathrm{m}^{-3}\right)\end{array}$} & \multicolumn{4}{|c|}{$K_{\mathrm{d}}(\lambda)\left(\mathrm{m}^{-1}\right)$} & \multirow[b]{2}{*}{$K_{\mathrm{d}}, \operatorname{PAR}(Z)$} \\
\hline & & & & & & & & & $305 \mathrm{~nm}$ & $325 \mathrm{~nm}$ & $340 \mathrm{~nm}$ & $380 \mathrm{~nm}$ & \\
\hline SD1 & $159^{\circ} 54^{\prime} \mathrm{E}$ & $18^{\circ} 00^{\prime} \mathrm{S}$ & 21 Feb 15 & 20:00 & 0.352 & 4125 & 101 & 1.15 & 0.173 & 0.116 & 0.093 & 0.05 & nd \\
\hline SD2 & $162^{\circ} 07^{\prime} \mathrm{E}$ & $18^{\circ} 37^{\prime} \mathrm{S}$ & 22 Feb 15 & $21: 45$ & 0.278 & 2430 & 70 & 0.122 & 0.194 & 0.119 & 0.099 & 0.057 & 0.026 \\
\hline SD3 & $164^{\circ} 54^{\prime} \mathrm{E}$ & $19^{\circ} 00^{\prime} \mathrm{S}$ & 24 Feb 15 & $03: 45$ & 0.236 & 445 & 70 & 0.08 & nd & nd & nd & nd & nd \\
\hline $\mathrm{LDA}^{*}$ & $164^{\circ} 41^{\prime} \mathrm{E}$ & $19^{\circ} 13^{\prime} \mathrm{S}$ & 25 Feb 15 & 13:00 & 0.22 & 974 & 100 & 0.1 & 0.074 & 0.041 & 0.029 & 0.012 & 0.024 \\
\hline SD4 & $168^{\circ} 00^{\prime} \mathrm{E}$ & $20^{\circ} 00^{\prime} \mathrm{S}$ & 04 Mar 15 & 08:30 & 0.199 & 1674 & 70 & 0.43 & nd & nd & nd & nd & nd \\
\hline SD5 & $170^{\circ} 00^{\prime} \mathrm{S}$ & $22^{\circ} 00^{\prime} \mathrm{S}$ & 05 Mar 15 & $05: 45$ & 0.258 & 902 & 70 & 0.26 & nd & 0.124 & 0.083 & 0.048 & nd \\
\hline SD6 & $172^{\circ} 08^{\prime} \mathrm{E}$ & $21^{\circ} 22^{\prime} \mathrm{S}$ & 06 Mar 15 & $03: 15$ & 0.265 & 935 & 130 & 0.05 & 0.159 & 0.108 & 0.087 & 0.044 & 0.025 \\
\hline SD7 & $174^{\circ} 16^{\prime} \mathrm{E}$ & $20^{\circ} 44^{\prime} \mathrm{S}$ & 07 Mar 15 & 00:00 & 0.186 & 1059 & 110 & 0.08 & 0.117 & 0.073 & 0.053 & 0.009 & 0.019 \\
\hline SD8 & $176^{\circ} 24^{\prime} \mathrm{E}$ & $20^{\circ} 06^{\prime} \mathrm{S}$ & 07 Mar 15 & 21:00 & 0.138 & 165 & 120 & 0.03 & 0.143 & 0.087 & 0.065 & 0.026 & 0.021 \\
\hline SD9 & $178^{\circ} 39^{\prime} \mathrm{E}$ & $20^{\circ} 57^{\prime} \mathrm{S}$ & 08 Mar 15 & $22: 15$ & 0.236 & 569 & 120 & 0.08 & 0.152 & 0.097 & 0.074 & 0.041 & 0.02 \\
\hline SD10 & $178^{\circ} 31^{\prime} \mathrm{W}$ & $20^{\circ} 28^{\prime} \mathrm{S}$ & 10 Mar 15 & 00:00 & 0.113 & 127 & 120 & 0.04 & 0.139 & 0.086 & 0.065 & 0.034 & 0.02 \\
\hline SD11 & $175^{\circ} 40^{\prime} \mathrm{W}$ & $19^{\circ} 59^{\prime} \mathrm{S}$ & 10 Mar 15 & $21: 45$ & 0.185 & 188 & 110 & 0.09 & 0.137 & 0.082 & 0.06 & 0.024 & 0.033 \\
\hline SD12 & $172^{\circ} 50^{\prime} \mathrm{W}$ & $19^{\circ} 29^{\prime} \mathrm{S}$ & 11 Mar 15 & 21:00 & 0.133 & 139 & 120 & 0.04 & 0.116 & 0.069 & 0.051 & 0.027 & 0.02 \\
\hline LDB* & $170^{\circ} 52^{\prime} \mathrm{W}$ & $18^{\circ} 14^{\prime} \mathrm{S}$ & 15 Mar 15 & 23:00 & 0.433 & 2950 & 52 & 0.24 & 0.172 & 0.11 & 0.087 & 0.054 & 0.028 \\
\hline SD13 & $169^{\circ} 04^{\prime} \mathrm{W}$ & $18^{\circ} 12^{\prime} \mathrm{S}$ & 21 Mar 15 & $22: 30$ & 0.0357 & 4 & 125 & 0 & nd & nd & nd & nd & nd \\
\hline $\mathrm{LDC}^{*}$ & $165^{\circ} 45^{\prime} \mathrm{W}$ & $18^{\circ} 41^{\prime} \mathrm{S}$ & 23 Mar 15 & 01:00 & 0.0231 & 0.82 & 135 & 0.01 & 0.189 & 0.116 & 0.09 & 0.054 & 0.02 \\
\hline SD14 & $163^{\circ} 00^{\prime} \mathrm{W}$ & $18^{\circ} 25^{\prime} \mathrm{S}$ & 30 Mar 15 & 01:30 & 0.045 & 0 & 165 & 0.04 & 0.105 & 0.056 & 0.04 & 0.023 & 0.018 \\
\hline SD15 & $160^{\circ} 00^{\prime} \mathrm{W}$ & $18^{\circ} 16^{\prime} \mathrm{S}$ & 31 Mar 15 & 00:00 & 0.061 & 0 & 110 & 0 & 0.097 & 0.054 & 0.039 & 0.021 & 0.016 \\
\hline
\end{tabular}

100342 were identified on board as "fiber tricho-like Trichodesmium" (FTL Tricho $)$, i.e., all particles of Trichodesmium with fusiform-shaped (tuff form) and round-shaped (puff form) colonies from $>200 \mu \mathrm{m}$ to $2-5 \mathrm{~mm}$ in size. FTL $\mathrm{F}_{\text {Tricho }}$ is assumed to be mostly Trichodesmium colonies with a possible risk that a small quantity of fibers could instead be diatoms chains. Contrary to a classical counting at the microscope, no abundance of free filaments is available, although these filaments represent often a significant part of the Trichodesmium assemblage (Carpenter et al., 2004). The FTL $_{\text {Tricho }}$ abundance is expressed in colonies per $\mathrm{m}^{-3}$ and measured at $5 \mathrm{~m}$ depth intervals (Picheral et al., 2010) pro-

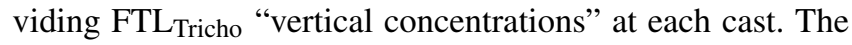
FTL $_{\text {Tricho }}$ abundance at $5 \mathrm{~m}$ depth was generally underestimated compared to that at $10 \mathrm{~m}$ and $15 \mathrm{~m}$ depths (possibly due to smaller size of colonies). Therefore, the value at $10 \mathrm{~m}$ was selected as representative of the abundance of the surface layer. As different FTL Tricho $_{\text {abundance profiles were ac- }}$ quired during the day (from 1 to 5 depending on the station), a daily average of the $10 \mathrm{~m} \mathrm{FTL}$ Tricho abundance was made. Daily average, maximum value of the day and the FTL Tricho abundance at noon (i.e., the nearest from the time of the Satlantic radiometric profile) were compared and showed no statistical difference. For the three long-duration stations, an average on 7 days of the $10 \mathrm{~m} \mathrm{FTL}$ Tricho abundance and a variation coefficient were calculated.

In order to estimate a trichome concentration, photographs taken with a Dino-Lite hand-held digital microscope covering the totality of the filtered surface on the GF/F filters ded- icated to absorption measurements were used. Colonies were first visually enumerated. The uncertainty on this colony and isolated filaments (essentially Katagnymene) visual enumeration was estimated at $10 \%$. The trichome concentration $\left(\mathrm{L}^{-1}\right)$ was estimated using a constant number of 10 trichomes per colony as representative of an average of each size class and shapes.

\subsection{Picoplankton}

Picoplankton population abundances were estimated by flow cytometry using a BD Influx flow cytometer (BD Biosciences, San Jose, CA, USA). Prochlorococcus (Proc), Synechococcus (Syn) and picoeukaryotes (Peuk) were enumerated using the red and orange fluorescence, while nonpigmented bacteria and protist groups were discriminated in a sample aliquot stained with SYBR Green I DNA dye, as described in Bock et al. (2018). Using a forward-scatter detector with the "small particle option" and focusing at 488 and $457 \mathrm{~nm}$ (200 and $300 \mathrm{~mW}$ solid state, respectively) laser into the same pinhole greatly improved the discrimination between the dim signal from Proc at the surface and background noise in unstained samples. Nanoeukaryotes (Neuk) were not further differentiated from Peuk. Cell abundances of Proc, Syn, Peuk and bacteria showed a vertical and uniform abundance distribution due to their mixing in the 0 $30 \mathrm{~m}$ layer (Bock et al., 2018). 


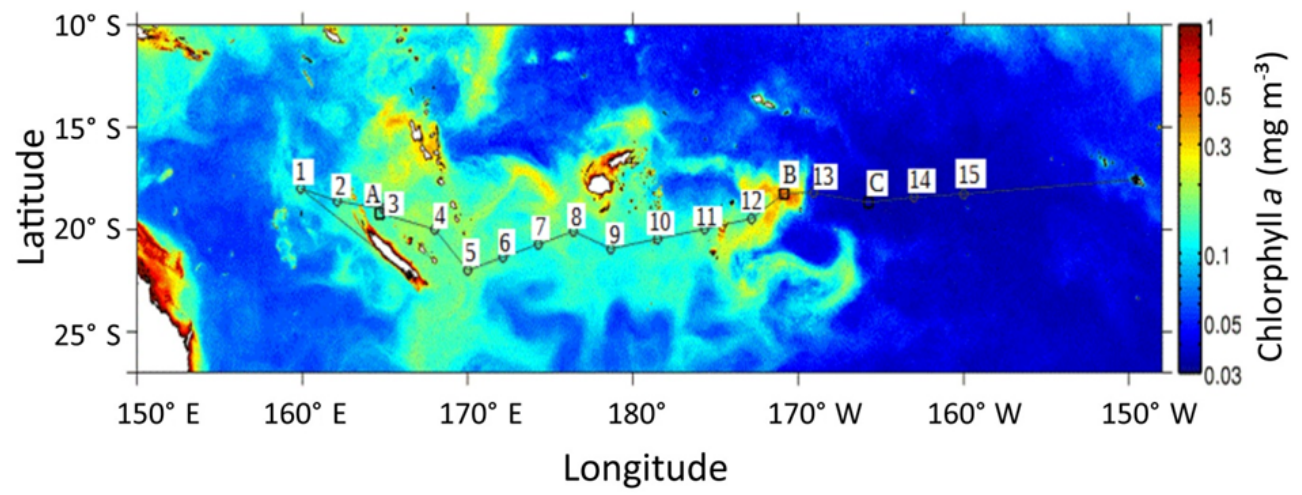

Figure 1. Map of chlorophyll distribution during the OUTPACE cruise (image composite of the Moderate Resolution Imaging Spectroradiometer - MODIS) data provided by CLS, Collect Localization Satellites). The positions of the 15 stations are shown by numbered squares, with $\mathrm{A}, \mathrm{B}$ and $\mathrm{C}$ representing long-duration stations (7 days), $\mathrm{A}$ in the Melanesian archipelago, B in the Fijian archipelago, $\mathrm{C}$ in the western part of the South Pacific Gyre.

\subsection{Chlorophyll $a$, phycoerythrin and pigment analyses}

For Chl $a$ determination by the fluorimetric method, filters were extracted with $5 \mathrm{~mL}$ methanol in darkness over a $2 \mathrm{~h}$ period at $4{ }^{\circ} \mathrm{C}$ and quantified using a Trilogy Turner fluorometer according to Le Bouteiller et al. (1992). HPLC pigment analyses on surface and DCM samples were performed according to the NASA protocol and provided monovinyl Chl $a$ (MV$\mathrm{Chl} a$ ), divinyl Chl A (DV-Chl $a$ ), accessory chlorophyll, and photosynthetic and photoprotective carotenoids (Hooker et al., 2012). PE was extracted in 50:50 glycerol/phosphate buffer. Quantification of this pigment was obtained from the area below the fluorescence excitation curve, using a calibrating procedure previously described (Wyman, 1992; Lantoine and Neveux, 1997; Neveux et al., 2006). Furthermore, pigment ratios were also used to estimate the relative importance of pico-, nano- and micro-plankton in terms of Chl $a$ using relative contributions of different accessory pigments divided by the sum of accessory pigments (Ras et al., 2008). The proportion of Proc to total Chl $a$ (TChl $a$ ) was estimated from the DV-Chl $a / \mathrm{TChl} a$ ratio. It usually represents a high proportion due to its high abundance despite its small size (Grob et al., 2007).

\subsection{Algorithms for Trichodesmium abundance estimates using pigments}

As a true microscopic determination of Trichodesmium abundance was not carried out at each station during the OUTPACE cruise, we used algorithms to derive trichome abundances from pigment concentrations (chlorophyll, zeaxanthin, $\mathrm{PE}>10 \mu \mathrm{m})$ and flow cytometric cell counting. Using a constant PE concentration per trichome (196 pg trichome ${ }^{-1}$ ) and a constant Chl $a$ per trichome $\left(100 \mathrm{pg} \mathrm{cell}^{-1}\right)$ as in Tenório et al. (2018), calculations of trichome concentration $\left(\mathrm{L}^{-1}\right)$ could be done both from PE or $\mathrm{Chl} a>10 \mu \mathrm{m}$, assuming that other autotrophic organisms have a negligi- ble contribution in this large size fraction. As Chl $a>10 \mu \mathrm{m}$ was not available for OUTPACE, total MV-Chl $a$ was used, which corresponds to the sum of $\mathrm{Chl} a$ from Syn and Trichodesmium, and all eukaryotic phytoplankton cells (pico-, nano- and microphytoplankton). MV-Chl $a$ associated with Syn and Peuk was estimated at the surface using measured cell concentrations and the Chl $a$ per cell values obtained on cultures grown under high light intensity conditions (Laviale and Neveux, 2011), i.e., $1.2 \mathrm{fg} \mathrm{cell}^{-1}$ for Syn and $10 \mathrm{fg} \mathrm{cell}^{-1}$ for Peuk $\left(10 \mathrm{fg} \mathrm{cell}^{-1}=\right.$ intermediate between the Chl $a$ per cell of Micromonas and the Chl a per cell of Ostreococcus). Peuk included also Neuk counts. Neglecting the rest of phytoplankton (larger cells; see Tenório et al. 2018) was possible. Microplankton biomass other than Trichodesmium was not significant at OUTPACE (as at DIAPALIS; Tenório et al. 2018). MV-Chl $a$ from Syn + Peuk including Neuk was then deduced from total MV-Chl $a$ to obtain MV-Chl $a$ associated with Trichodesmium. The Trichodesmium spp. abundance was also estimated from total zeaxanthin (TZea). For this, Zea per Proc cell (Zea-Proc) was determined in the area where Trichodesmium is absent and assuming a constant Zea concentration per Syn cell (Zea-Syn) determined on Syn cultures under high light intensity conditions (Laviale and Neveux, 2011). The Zea Trichodesmium was then deduced by subtracting Zea-(Proc + Syn) from TZea (Zea associated with chlorophytes being considered as negligible). Trichodesmium abundance was deduced from Zea concentration per colony found in Carpenter et al. (1993). We then compared estimations of Trichodesmium from these pigment algorithms to $\mathrm{FTL}_{\text {Tricho }}$ abundance and trichome concentration estimated from visual counts.

\subsection{Particulate and CDOM absorption, backscattering measurements}

Light absorption spectra were measured directly with filters soaked in filtered seawater, by referencing them to an equally 

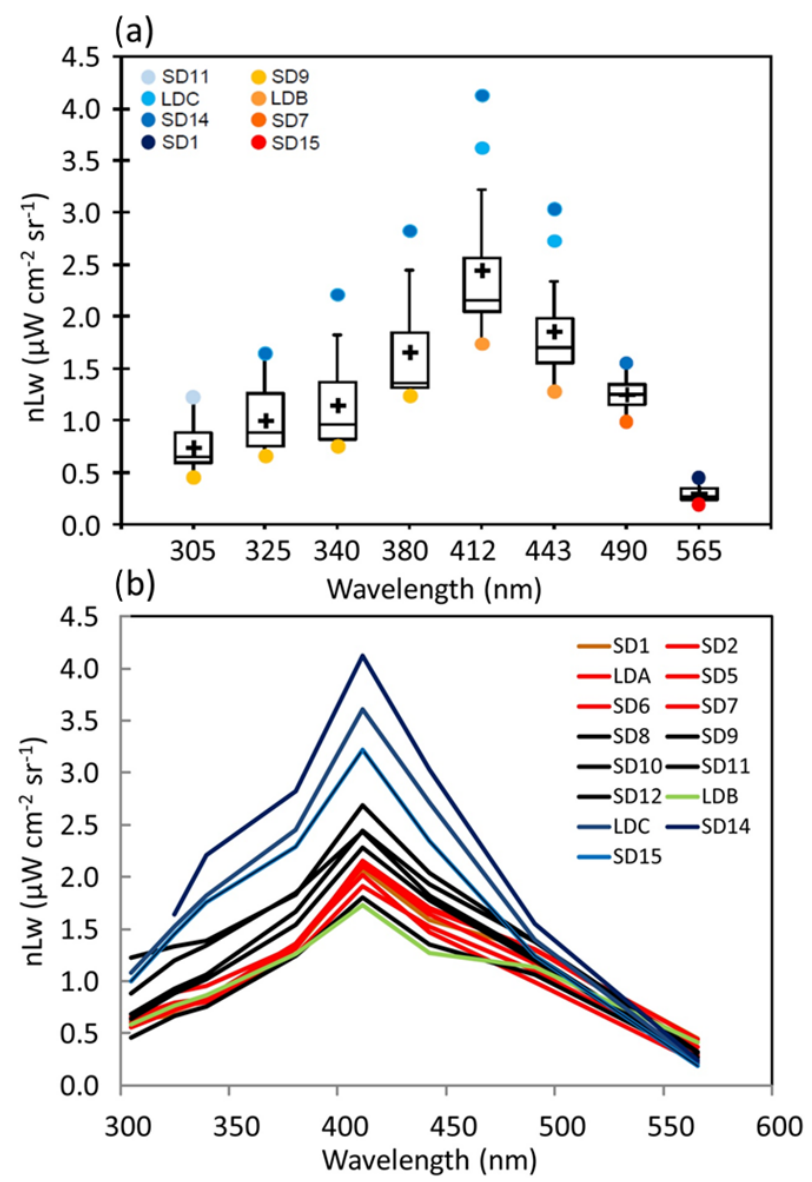

Figure 2. OUTPACE AOPs in the western tropical South Pacific. (a) Box-and-whisker plots for the distribution of $\mathrm{nL}_{\mathrm{w}}(\lambda)$ in the UV $(305,325,340$ and $380 \mathrm{~nm})$ and visible $(412,443,490$ and $565 \mathrm{~nm})$ spectral domains determined between 0 and $30 \mathrm{~m}$ at stations in the Melanesian archipelago (MA, SD1-SD7 and LDA), Fijian archipelago (FI, SD8-SD11) and South Pacific Gyre (SPG, SD13, LDC, SD14, SD15). The outlier stations are indicated in the upper left (see text). (b) $\mathrm{nL}_{\mathrm{W}}(\lambda)$ with color code depending on TChl $a$ (in red: high concentrations $\left(0.185<\mathrm{TChl} a<0.35 \mathrm{mg} \mathrm{m}^{-3} ; \mathrm{SD} 1\right.$ to SD7, Melanesian archipelago), in black: median concentrations $\left(0.06<\right.$ TChl $a<0.1 \mathrm{mg} \mathrm{m}^{-3} ;$ SD8 to SD11 around islands of Fiji), in blue: low concentrations (TChl $a<0.11 \mathrm{mg} \mathrm{m}^{-3}$; SD14 to SD15 including LDC) with the frontal station LDB in green (Table 1)).

soaked empty filter. Measurements were done in a singlebeam Beckman DU-600 spectrophotometer with filtered seawater. Absorbance (optical density) spectra were acquired between 300 and $800 \mathrm{~nm}$ in $2 \mathrm{~nm}$ steps. To correct the pathlength amplification effect on filters, the optical density of the equivalent suspension (ODs) was obtained from the optical density on filter $(\mathrm{ODf})$ as $\mathrm{ODs}=A \mathrm{ODf}+B(\mathrm{ODf})^{2}$ with $A$ and $B$ coefficients determined by Mitchell et al. (1990) as used in oligo- to mesotrophic waters in the Pacific Ocean (Dupouy et al., 1997, 2003, 2010). All spectra were shifted to zero in the infrared by subtracting the average optical den- sity between 750 and $800 \mathrm{~nm}$. Optical densities were finally converted into the total particulate absorption coefficients $\left(a_{P}(\lambda)\right.$ in $\left.\mathrm{m}^{-1}\right)$. The UV absorption by MAAs can be amplified by freezing of filters (Carreto and Carrignan, 2011). The $a_{P}(330)$ to $a_{P}(676)$ ratio was calculated as photoprotection index related to MAAs $(330 \mathrm{~nm}$ : absorption maximum of shinorine) in total phytoplankton $(676 \mathrm{~nm}$, absorption maximum of Chl $a$ ), as in Ferreira et al. (2013). CDOM absorption spectra were measured on board with a $200 \mathrm{~cm}$ pathlength liquid waveguide capillary cell (LWCC, WPI) as described in Martias et al. (2018). A broad peak around $350 \mathrm{~nm}$ was visible in most of the CDOM spectra, except for LDB and SPG stations (not shown).

Backscattering coefficients were determined with the default correction $(\sigma)$ applied to compensate for the loss of photons absorbed by the medium between the instrument and the detection volume as described in Dupouy et al. (2010) from a HydroScat 6 (HOBI Labs, Inc) at six wavelengths $(412,442,510,550,620$ and $676 \mathrm{~nm})$. The particulate backscattering $\left(b_{\mathrm{bp}}(\lambda)\right.$ in $\left.\mathrm{m}^{-1}\right)$ was obtained by subtracting the backscattering coefficient of pure water, $b_{\mathrm{bw}}$ (Morel and Maritorena, 2001). Due to an electrical shortage inside the instrument, only stations SD1-SD6 and LDA days $1-5$ were available, and no stations were sampled after SD6. Backscattering coefficients of surface oligotrophic waters (SD13, LDC, SD14, SD15), which are supposed to depend deeply on TChl $a$ according to Huot et al. (2008) for the southeastern Pacific, were deduced from Chl $a$ using a look-up table of data obtained during DIAPALIS (DIAzotrophy in the Pacific on ALIS) cruises in the Loyalty Channel (Dupouy et al., 2010).

\subsection{Statistics}

Ocean Data View (sections Schlitzer, R., Ocean Data View, http://odv.awi.de, last access: 20 August 2018, 2016) was employed for the spatial representation of biogeochemical parameters over the vertical $(0-150 \mathrm{~m})$. The spatial interpolation/gridding of data was performed using Data-Interpolating Variational Analysis (DIVA). Principal component analyses (PCAs) were conducted on the basis of Pearson's correlation matrices using XLSTAT 2011.2.05.

\section{Results}

\subsection{Distributions of $\mathrm{nL}_{\mathrm{w}}(\lambda), \mathrm{K}_{d}(\lambda)$ and $Z 10 \%(\lambda)$}

Along the OUTPACE transect, $\mathrm{nL}_{\mathrm{w}}(\lambda)$ showed a large range of values and spectral shape (Fig. 2a). In the UV (305$380 \mathrm{~nm})$, violet $(412 \mathrm{~nm})$ and blue $(443$ and $490 \mathrm{~nm}), \mathrm{nL}_{\mathrm{w}}(\lambda)$ values were the lowest in the MA, increasing towards the SPG (SD14-SD15, LDC). For all the wavebands, with the exception of the yellowish green one $(565 \mathrm{~nm}), \mathrm{nL}_{\mathrm{w}}(\lambda)$ at SD14 and LDC was higher than the 90th percentile, and $\mathrm{nL}_{\mathrm{w}}(\lambda)$ values at SD9 and LDB were lower than the 10th 
percentile (Fig. 2a). Values of $\mathrm{nL}_{\mathrm{w}}(\lambda)$ in this violet-blue domain were similar to those measured in the most oligotrophic oceanic areas at the eastern part of the OUTPACE transect (Tedetti et al., 2010). For example, in the center of the SPG during the BIOSOPE cruise $\left(20-30^{\circ} \mathrm{S}, 142-126^{\circ} \mathrm{W}\right)$, $\mathrm{nL}_{\mathrm{w}}(412), \mathrm{nL}_{\mathrm{w}}(443)$ and $\mathrm{nL}_{\mathrm{w}}(490)$ reached up to $4.5,4$ and $2 \mu \mathrm{W} \mathrm{cm} \mathrm{cm}^{-2} \mathrm{sr}^{-1}$, respectively, for TChl $a$ concentrations $<0.022 \mathrm{mg} \mathrm{m}^{-3}$ and with a DCM at $180 \mathrm{~m}$. The frontal station LDB at OUTPACE exhibited a peculiar spectrum with waters greener than all other stations (Fig. 2b). The low $\mathrm{nL}_{\mathrm{w}}$ corresponded to a high TChl $a$ concentration of $0.43 \mathrm{mg} \mathrm{m}^{-3}$ formed by Trichodesmium and picoplankton on a surface physical front (Rousselet et al., 2018). Moreover, the GF/F filters used for absorption at these stations showed an orangeyellow color when observed under the Dino-Lite microscope. Such a color was not observed in the MA and is typical of small picoplanktonic cells such as Pro and Syn.

For all stations, $K_{\mathrm{d}}(\lambda)$ decreased from the UV-B to UVA spectral domain (Table 1). From the MA to the FI, $K_{\mathrm{d}}(\lambda)(325)$ was high from SD1 to SD6, then decreased from SD7 to SD12, and showed a peak at LDB, and minimum at the SPG stations. During the 5-day long-duration stations, $K_{\mathrm{d}}(325)$ variations (not shown) reflected those of TChl $a$ with values decreasing from day 1 to 5 at LDA (0.11 to $\left.0.09 \mathrm{~m}^{-1}\right)$ and LDB $\left(0.13\right.$ to $\left.0.11 \mathrm{~m}^{-1}\right)$ and remained stable at LDC $\left(0.05 \mathrm{~m}^{-1}\right) . K_{\mathrm{d}}(\mathrm{PAR})$ showed the same tendency at LDA and LDB $\left(0.028\right.$ to $\left.0.023 \mathrm{~m}^{-1}\right)$, and LDC $\left(0.020 \mathrm{~m}^{-1}\right)$. These typical low values of $K_{\mathrm{d}}(\mathrm{PAR})$ in oligotrophic waters were associated with DCMs at 125, 165, 110 and $135 \mathrm{~m}$ and a TChl $a$ concentration of $0.036,0.045$, 0.048 and $0.023 \mathrm{mg} \mathrm{m}^{-3}$ measured at SD13, SD14, SD15 and LDC, respectively. Such values are close to those found in the southeastern Pacific during the BIOSOPE cruise (08$35^{\circ} \mathrm{S}, 142-73^{\circ} \mathrm{W}$ ) (Tedetti et al., 2007) and much lower than those reported for the oligotrophic waters of NW Mediterranean Sea (Sempéré et al., 2015). Maxima of Z10\%(380) (Table 1; Fig. 3) were found in the FI in the oligotrophic part of the transect (LDC and SD15, 100-120 m, for a TChl $a$ concentration of $0.02 \mathrm{mg} \mathrm{m}^{-3}$ ) and were comparable to those reported for the clearest natural waters in SPG (Tedetti et al., 2007). Conversely, stations exhibiting the lowest Z10\% (SD1, $40 \mathrm{~m}$ ) were found in the MA and also at the frontal station LDB in the FI (DCM of $41 \mathrm{~m}$, TChl $a=0.433 \mathrm{mg} \mathrm{m}^{-3}$ ). The first optical depth determined in the UV-visible varied from $13 \mathrm{~m}$ (LDB day 3) to $28 \mathrm{~m}$ (SD14).

\subsection{Pigment composition and abundance of phytoplanktonic groups}

\subsubsection{FTL Tricho abundance derived from the Underwater Vision Profiler}

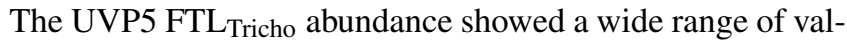
ues along the transect SD1-SD15 (Fig. 4a; Table 1). It was essentially concentrated in the upper $50 \mathrm{~m}$, although some

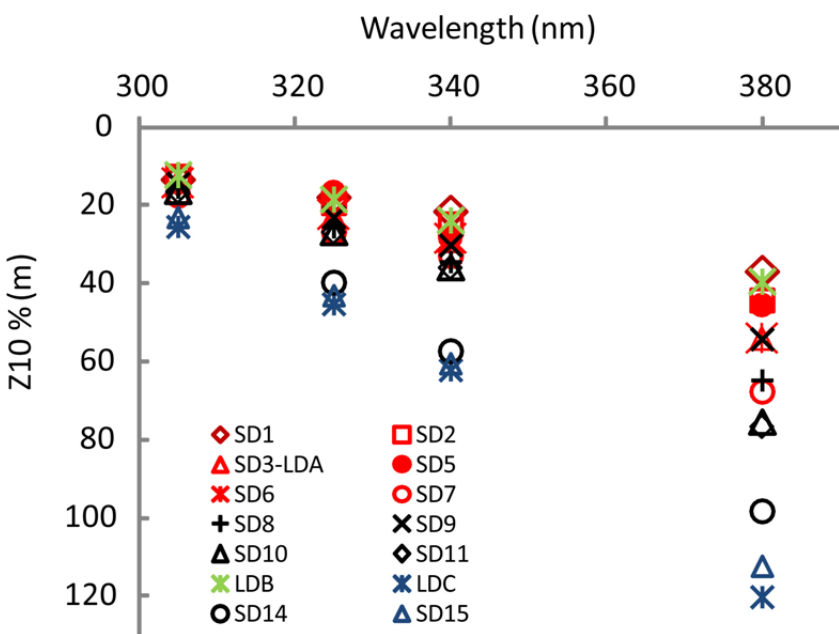

Figure 3. OUTPACE AOPs (continued). $Z_{10 \%}(\lambda)$ at $305 \mathrm{~nm}$ (UV$\mathrm{B}$ ), and 325,340 and $380 \mathrm{~nm}$ (UV-A) at all stations during OUTPACE in the western tropical South Pacific with color code depending on TChl $a$ (in red: high concentrations $(0.185<$ TChl $a<$ $0.35 \mathrm{mg} \mathrm{m}^{-3}$; SD1 to SD7, Melanesian archipelago), in black: median concentrations $\left(0.06<\mathrm{TChl} a<0.1 \mathrm{mg} \mathrm{m}^{-3}\right.$; SD8 to SD11 around the islands of Fiji), in blue: low concentrations (TChl $a$ $<0.11 \mathrm{mg} \mathrm{m}^{-3}$; SD14 to SD15 including LDC) with the frontal station LDB in green (Table 1)).

colonies were still visible below. The maximum was obtained at SD1 (at $10 \mathrm{~m}, 7663$ colonies $\mathrm{m}^{-3}$ ) and rapidly dropped to 2000 colonies $\mathrm{m}^{-3}$ at SD2 to stabilize between 200 and 500 colonies $\mathrm{m}^{-3}$ at the east of SD4. It progressively decreased from west to east. Still visible at $\operatorname{SD5}\left(170^{\circ} \mathrm{E}\right)$, it vanished at SD7, where the maximum of $\mathrm{FTL}_{\text {Tricho }}$ abundance was located deeper and finally disappeared between SD8 and SD11. On the first day of LDB, an exceptional high value of 3700 colonies $\mathrm{m}^{-3}$ was observed. During the longduration stations, the average (CV) of $10 \mathrm{~m}$ Trichodesmium abundance was $1000 \mathrm{~m}^{-3}(35 \%)$ at LDA, $1726 \mathrm{~m}^{-3}(9 \%)$ at LDB and $2 \mathrm{~m}^{-3}(1 \%)$ at LDC. FTL Tricho abundance allowed one to define three groups of stations, according to the $\log 10$ of abundance. The first group was composed of the stations SD1 to SD7, and included both LDA in the western MA and LDB in the FI $(\log 10>2.8)$. The second group was composed of SD3, and SD8 to SD12 with medium concentrations $(2<\log 10<2.8)$. Finally, the third group contained the stations SD13, SD14, LDC and SD15 characterized by no or very low $\mathrm{FTL}_{\text {Tricho }}$ abundance $(\log 10<2)$.

\subsubsection{Picoplankton abundance and influence on TChl $a$}

Picoplankton predominance was typical of oligotrophic waters (Neveux et al., 1999; Buitenhuis et al., 2012; Bock et al., 2018). The Syn abundance was particularly high in the surface layer in the MA at SD3-LDA $\left(>22 \times 10^{3}\right.$ cells mL $\left.{ }^{-1}\right)$ until the intermediate area of the Fijian basin. However, the Syn surface maximum was observed at LDB $(>100 \times$ 


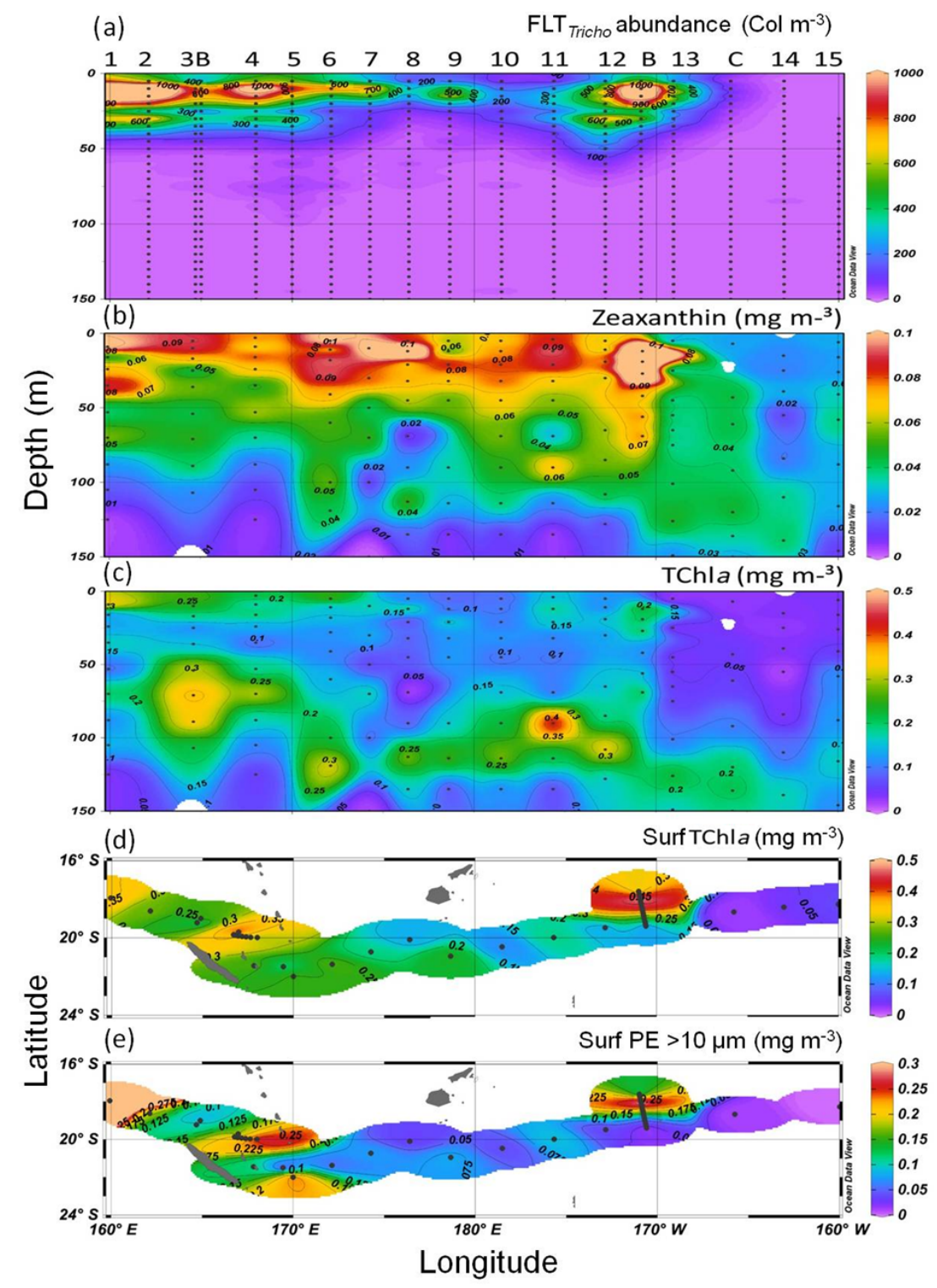

Figure 4. Sections from 0 to $150 \mathrm{~m}$ of (a) abundance of FTL $\mathrm{Tricho}\left(\mathrm{N} \mathrm{m}^{-3}\right)$, (b) zeaxanthin and (c) TChl $a$ concentration (mg m $\left.{ }^{-3}\right)$ measured by HPLC. Surface maps of (d) TChl $a$ and (e) PE $>10 \mu \mathrm{m}\left(\mathrm{mg} \mathrm{m}^{-3}\right)$. Short transects TChl $a$ HPLC NASA data from pump samples (sampling at $3.2 \mathrm{~m}$ depth) at $165^{\circ} \mathrm{E}$ and $170^{\circ} \mathrm{W}$ are included in the mapping. Source: Ocean Data View (sections Schlitzer, R., Ocean Data View, http://odv.awi.de (last access: 20 August 2018), 2016). Station positions are indicated by black circles.

$10^{3}$ cells $\mathrm{mL}^{-1}$ ), together with Proc abundance peaking at LDB with more than $9 \times 10^{5}$ cells $\mathrm{mL}^{-1}$ in the upper surface layer and a small Peuk abundance of 850 cells $\mathrm{mL}^{-1}$. Note that the Peuk abundance was high ( $>3000$ cells $\mathrm{mL}^{-1}$ ) at the DCM only.

\subsubsection{Chlorophyll $a, \mathrm{PE}$ and accessory pigments}

HPLC pigment analyses revealed the occurrence of four major pigments identified as MV-Chl $a, \mathrm{DV}-\mathrm{Chl} a$, zeaxanthin and $\beta$-carotene. HPLC pigment concentrations from LOV were used since they were available for each station and depth (Fig. 4b-c). The $0-150 \mathrm{~m}$ section of zeaxanthin concentration, the main photoprotective carotenoid contained in all cyanobacteria (Syn, Proc + Trichodesmium), showed values $>0.15 \mathrm{mg} \mathrm{m}^{-3}$ in the $0-50 \mathrm{~m}$ layer and almost continuously from SDA to SD12. Furthermore, a strong maximum was observed at the frontal LDB (Fig. 4b). TChl $a$-LOV and TChl $a$-NASA (from a regression between only $5 \mathrm{~m}$ and DCM values) were highly correlated (TChl $a$-LOV $=$ $0.81 \times$ TChl $a$-NASA; $r^{2}=0.87, p<0.05, n=12$ and zeaLOV $=0.71 \times$ zea - NASA; $r^{2}=0.88, p<0.05, n=12$; $p<0.0001)$. However, this good relation was obtained on different bottle casts. TChl $a$ section (LOV: Fig. 4c) showed 

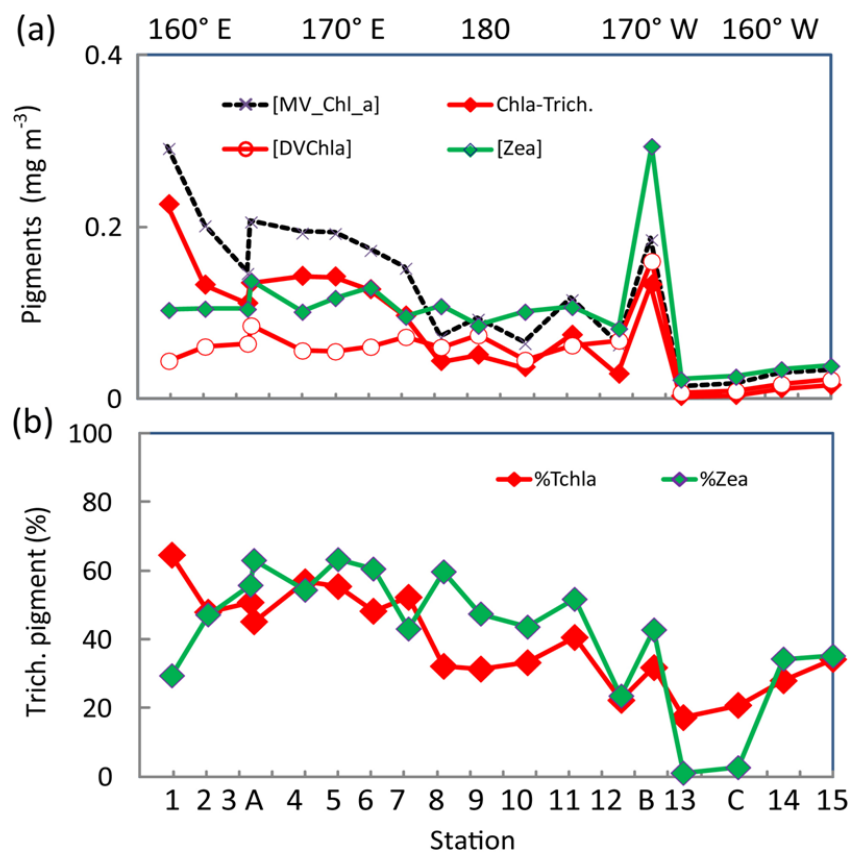

Figure 5. (a) Surface concentrations $\left(\mathrm{mg} \mathrm{m}^{-3}\right)$ along the OUTPACE transect of DV-Chl $a$, total zeaxanthin, total MV-Chl $a$ and MV-Chl $a$ related to Trichodesmium (Chl $a$ Trich.) as obtained by appliance of pigment algorithms (see material and methods), (b) Contribution of Trichodesmium to TChl $a$ and zeaxanthin (\%). Pigments were analyzed by HPLC at NASA. The $x$ axis represents station number (below) and main longitudes (above).

high values in the MA near the islands of New Caledonia and Vanuatu (SD1 to SD6) (with a maximum of $0.352 \mathrm{mg} \mathrm{m}^{-3}$ at SD1 at $5 \mathrm{~m}$ ), and a DCM oscillating between 70 and $110 \mathrm{~m}$ (Table 1), with a higher value $\left(0.534 \mathrm{mg} \mathrm{m}^{-3}\right)$ and a shallower DCM (52 m) at the frontal LDB. Surface PE $>10 \mu \mathrm{m}$ values (indicative of Trichodesmium) showed two spots of high concentrations (Fig. 4e). The first spot is located in the western part of the MA (SD1 to SD5), and the second is located at LDB. PE $>10 \mu \mathrm{m}$ was low in the central part of the transect (between SD6 and SD12) and was near 0 in the SPG. Higher surface values of TChl $a$ and PE $>10 \mu \mathrm{m}$ at LDA and LDB (Fig. 4d, e) were obtained from pump samples and provided higher values than surface Niskin samples.

DV-Chl $a$ of Proc at the surface (Fig. 5a) tended to increase from west to east until a prominent maximum of $0.18 \mathrm{mg} \mathrm{m}^{-3}$ at the frontal LDB and showed minimum concentrations, higher to the east, in the SPG. It represented $22 \%$ of TChl $a$ in the MA, $39 \%$ in the FI and up to $39 \%$ in the SPG (and $45 \%$ at LDB). The estimates of MV-Chl $a$ in Trichodesmium populations (Chl $a$-Trich.) using pigment algorithm (see Sect. 2.6) were between 0.10 and $0.23 \mathrm{mg} \mathrm{m}^{-3}$ in the MA, around $0.03 \mathrm{mg} \mathrm{m}^{-3}$ in the FI, with a high value of $0.08 \mathrm{mg} \mathrm{m}^{-3}$ at LDB and lower than $0.02 \mathrm{mg} \mathrm{m}^{-3}$ in the SPG (Fig. 5a). Its contribution to TChl $a$ (Fig. 5b) varied from $52 \%$ in the MA (mean of \% contribution from SD1 to
SD7) and $30 \%$ in the FI, and it was still $23 \%$ of TChl $a$ in the SPG (SD12-LDC). Its percent contribution at LDB was lower $(31 \%)$ because of a high contribution of DV-Chl $a$. Identical contributions were calculated either using LOV or NASA surface pigments. The contribution of Trichodesmium zeaxanthin followed roughly the same pattern, with a contribution of 53, 40 and only $3 \%$ in the MA, FI and SPG, respectively. Note that the contributions to TChl $a$ or zeaxanthin in the SPG are indicative only, as they are calculated on values $<0.03 \mathrm{mg} \mathrm{m}^{-3}$. The zeaxanthin contribution was lower at SD1 and was somewhat higher between SD8 and SD11 than the contribution to TChl $a$ (Fig. 5b).

\subsubsection{Trichome concentration}

The Trichodesmium distribution at the surface deduced from visual counts, UVP5 and pigment algorithms showed grossly similar pattern (Fig. 6). However, at a given site, differences in trichome estimates could be observed according to the method used. These differences could be partly due to patchiness distribution of trichomes (and colonies) and no concomitant sampling of the different parameters. Nevertheless, significant linear correlations between trichome concentrations estimated from $\mathrm{PE}>10 \mu \mathrm{m}$, or Chl $a$-trichome, or microscopic visual counts, and FTL ${ }_{\text {Tricho }}$ abundance were observed (Fig. 7a). The relatively high slopes of the linear regressions (i.e., 675, 735, 529, as factors between large colonies and trichomes, from $\mathrm{PE}>10 \mu \mathrm{m}$ and $\mathrm{Chl} a$, or visual counts respectively) are explained by the fact that FTL $_{\text {Tricho }}$ counted by the UVP5 represented only the number of the largest colonies of Trichodesmium (without true determination of trichome number by colony). The correlation between $\mathrm{Chl} a$-trichome and our microscopic visual counts $\left(r^{2}=0.74\right)$ was also significant (Fig. 7b). A maximum of 4715 trichomes $\mathrm{L}^{-1}$ was enumerated on the filter during the Simbada transect from pump samples between SD3 and SD4, at $20^{\circ} \mathrm{S}, 16730^{\circ} \mathrm{E}$ with TChl $a$ of 0.3 to $0.5 \mathrm{mg} \mathrm{m}^{-3}$.

\subsection{Backscattering and absorption coefficients, photoprotection index}

All particulate backscattering spectra showed large troughs due to absorption maxima by particulate material in the blue (440, $480 \mathrm{~nm}$ ) channels (Fig. 8a) as pigment absorption has been shown to influence backscattering intensity (Stramski et al., 2008). At the most concentrated Trichodesmium stations (slick, SD1), the backscattering coefficient $\left(b_{\mathrm{bp}-\mathrm{H} 6}\right)$ was twice higher (at $510 \mathrm{~nm}, 0.007 \mathrm{~m}^{-1}$ ) than in the stations where they were moderately present (SD2-SD6) (as a mean at $510 \mathrm{~nm}: 0.0025 \mathrm{~m}^{-1}$ ) compared to the value for pure water of $0.0013 \mathrm{~m}^{-1}$ at $510 \mathrm{~nm}$ (Morel et al., 2007). The slopes of the $b_{\mathrm{bp}-\mathrm{H} 6}$ spectra calculated without the blue channels but including the $676 \mathrm{~nm}$ channel (i.e., from 510 to $676 \mathrm{~nm}$ ), as the latter was not biased by $\mathrm{Chl} a$ fluorescence (Stramski et al., 2008) were in the range 0.0017 to $0.0022 \mathrm{~m}^{2} \mathrm{~nm}^{-1}$, typi- 


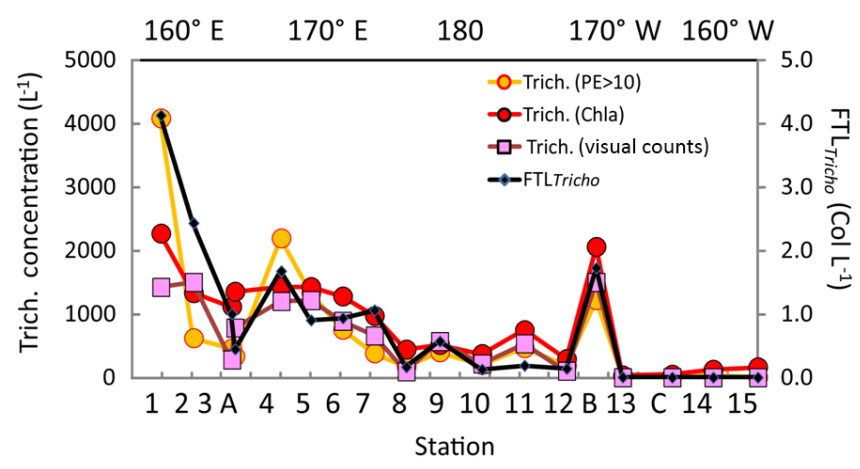

Figure 6. Surface values along the OUTPACE transect of the Trichodesmium abundance, in terms of trichome $\mathrm{L}^{-1}$ (left axis), deduced from different methods: (1) visual counts, (2) pigment algorithms using TChl $a$ Trich. (Chl $a$ ), or phycoerythrin in the $>10 \mu \mathrm{m}$ fraction Trich. $(\mathrm{PE}>10 \mu \mathrm{m})$. Comparison with $\mathrm{FTL}_{\text {Tricho }}$ abundance (colony counts in colonies $\mathrm{L}^{-1}$ by UVP5 at $10 \mathrm{~m}$, right axis). The $x$ axis represents the station number (below) or the main longitudes (above).
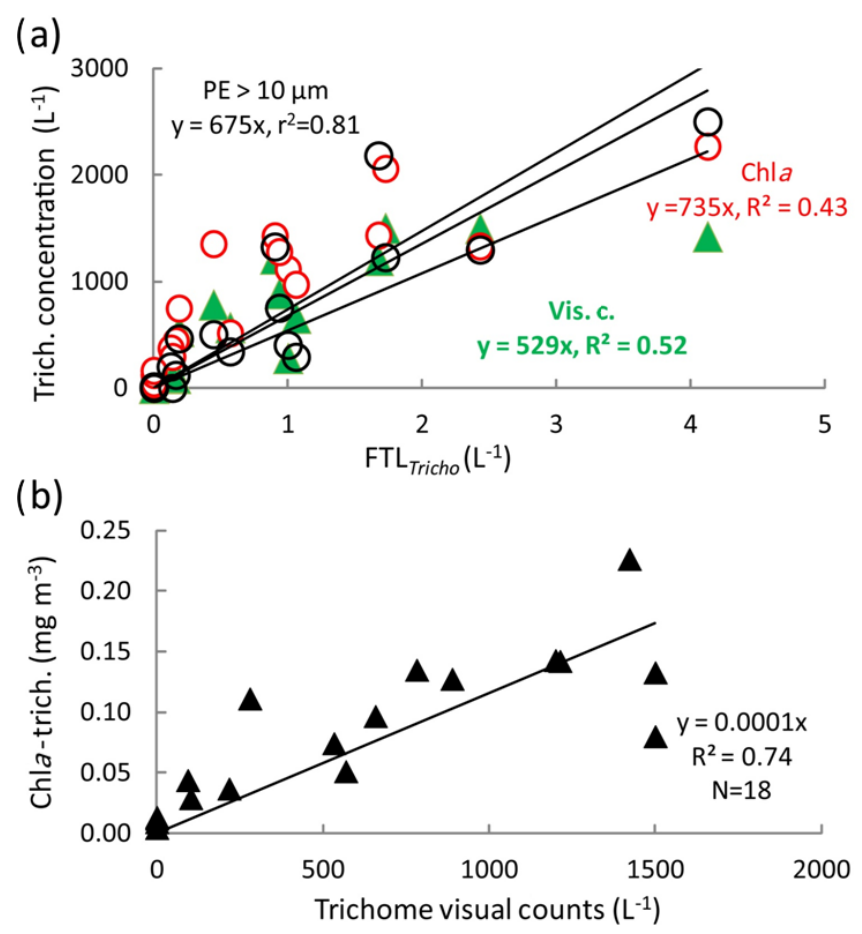

Figure 7. Correlations between the (a) trichome concentration estimated from $\mathrm{PE}>10 \mu \mathrm{m}$ (in black) or Chl $a$ (Trich.) (in red) or vi-

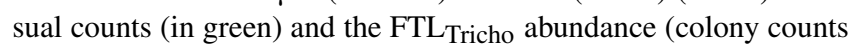
by UVP5 in $\mathrm{L}^{-1}$ ), (b) Chl $a$ (Trich.) versus trichome concentration from visual counts (trichome $\mathrm{L}^{-1}$ ).

cal of large cells. The TChl $a$-specific backscattering coefficient was higher in slicks $\left(0.017 \mathrm{~m}^{2} \mathrm{mg}(\mathrm{Chl} a)^{-1}\right)$ and lower in SD3-LDA $\left(0.006 \mathrm{~m}^{2} \mathrm{mg}(\mathrm{Chl} a)^{-1}\right)$ near the ones determined on colonies (Dupouy et al., 2008). The section from 0 to $150 \mathrm{~m}$ of $b_{\mathrm{bp}-\mathrm{H} 6}$ showed that the high backscattering co- efficient characterizes the $0-10 \mathrm{~m}$ layer in the MA (no data were collected after SD6; Fig. 8b).

Typical spectra of particulate absorption for Trichodesmium-rich waters exhibit the two MAA absorption peaks at 330 and $360 \mathrm{~nm}$ with a much lower intensity for the $360 \mathrm{~nm}$ peak (Fig. 9a). These peaks are characteristic of Trichodesmium spectra (Dupouy et al., 2008), and their amplitude was largely enhanced by freezing (as found on dinoflagellates by Laurion et al., 2003; Carreto and Carrignan, 2011). This MAA absorption has been used in many studies to show the degree of photoprotection of phytoplankton against UV (Ferreira et al., 2013). They were not observed at the surface in low Trichodesmium concentrations $\left(\mathrm{FTL}_{\text {Tricho }}\right.$ abundance; Fig. $\left.9 \mathrm{~b}\right)$. Sections from 0 to $150 \mathrm{~m}$ of $a_{P}(330)$ and $a_{P}(440)$ (Fig. 9c) exhibit the impact of MAAs in the upper layer at $330 \mathrm{~nm}\left(a_{P}(330)>0.4 \mathrm{~m}^{-1}\right)$. At $442 \mathrm{~nm}$, there was no increase on the surface layer by $\mathrm{FTL}_{\text {Tricho }}$ and the highest values are rather linked to the DCM at $80 \mathrm{~m}\left(a_{P}(440)>0.2 \mathrm{~m}^{-1}\right)$. A reasonable relationship (Fig. 10a) was found between UVP-5 FTL Tricho abundance and $a_{P}(330)$ when considering the entire 0 $150 \mathrm{~m}$ layer $\left(\mathrm{FTL}_{\text {Tricho }}\right.$ abundance $=0.43 \times a_{P}(330)-2.1$, $\left.r^{2}=0.57, n=120, p<0.0001\right)$, also indicating that the freezing effect remained proportional to the concentration for our dataset.

The $a_{P}(330) / a_{P}(676)$ ratio showed relatively high values $(>80)$ from 0 to $25 \mathrm{~m}$; then it abruptly fell to 20 below $30 \mathrm{~m}$ depth (Fig. 10b). When considering the surface layer only (Fig. 10c), the MAA index was tightly related to Trichodesmium, except at some stations (SD10). Indeed, MAA pigments are also produced by other phytoplankton groups (Carreto and Carignan, 2011) when exposed to high $\mathrm{nL}_{\mathrm{w}}(\mathrm{UV})$ values. MAAs of other groups show generally only one peak at $320 \mathrm{~nm}$ as in the southeastern Pacific (Bricaud et al., 2010) or at $330 \mathrm{~nm}$ (large phytoplankton in Argentina's continental shelf; Ferreira et al., 2013). At OUTPACE, phytoplankton counts indicate that the contribution of other large phytoplankton (shown by the size index from HPLC pigment ratios) was low. Nevertheless, a discrepancy was observed around SD10, where high values of $a_{P}(330) / a_{P}(676)$ ratio corresponded to low UVP5 FTL Tricho $_{\text {and visual counts could }}$ be explained by a higher concentration of other photoprotected non-cyanobacterial phytoplankton (the second peak at $360 \mathrm{~nm}$ was less pronounced), or a spatial heterogeneity in sampling. At LDB, the mixing with Proc decreased the photoprotection index drastically.

\subsection{Relationship between AOPs and pigments}

In the present study, Chl $a$ was well correlated to all $\mathrm{nL}_{\mathrm{w}}(\lambda)$ ratios $\left(\mathrm{nL}_{\mathrm{w}}(\lambda) / \mathrm{nL}_{\mathrm{w}}(565)\right)$ with $r^{2}$ varying from 0.79 to 0.83 (power regressions) with RMSE (not shown) ranging from 51 to $30 \%$ from 305 to $490 \mathrm{~nm}$ for OUTPACE and from 36 to $23 \%$ for BIOSOPE according to wavelength considered (Fig. 11). The relations between $\mathrm{nL}_{\mathrm{w}}(\lambda)$ and $\mathrm{Chl} a$ were 
(a)

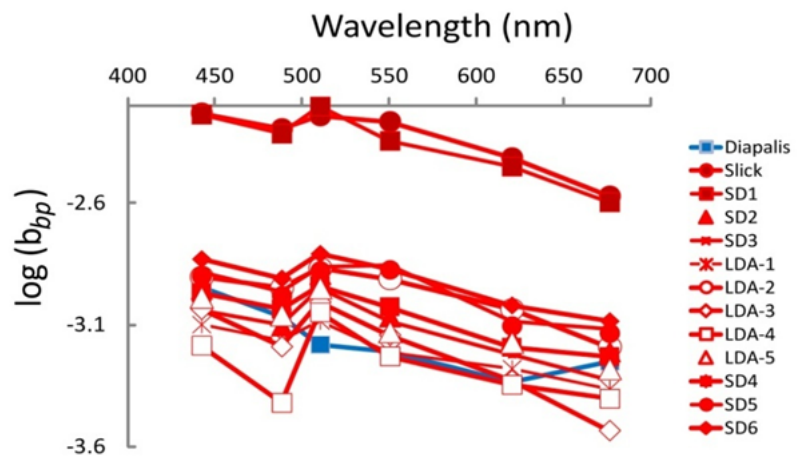

(b)

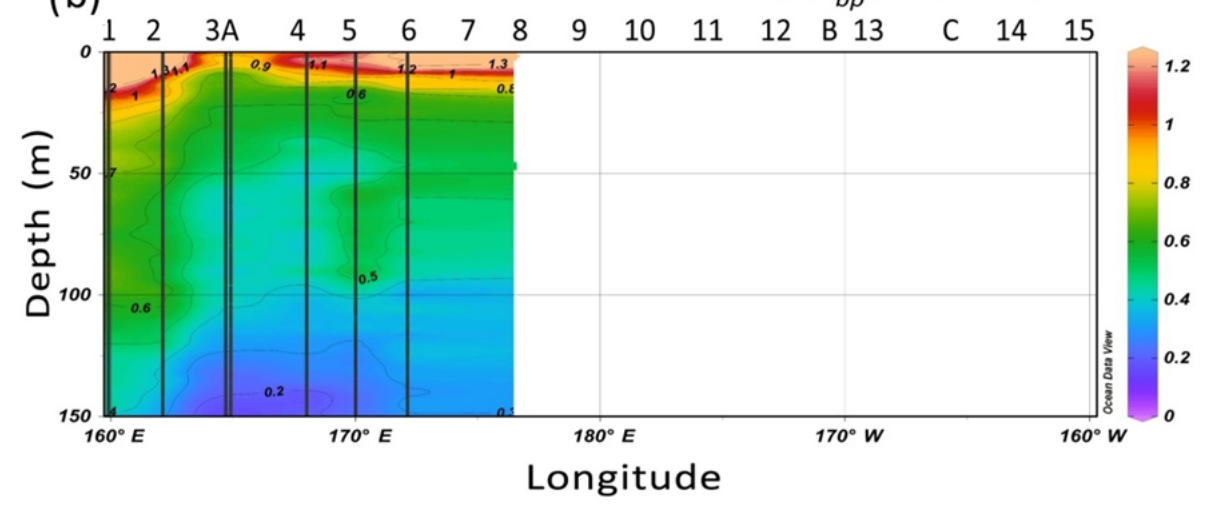

Figure 8. IOPs: (a) backscattering spectrum $\left(\log \left(b_{\mathrm{bp}}\right)\right.$ in $\left.\mathrm{m}^{-1}\right)$ vs. wavelength measured by a HOBI Labs HydroScat-6 in Trichodesmiumrich waters showing troughs at the maximum absorption wavelengths (in red). Comparison with data measured at an oceanic station of the DIAPALIS $2001-2003$ program $\left(167^{\circ} \mathrm{E}, 2^{\circ} \mathrm{S}\right.$,) with the same H6, (c) section from 0 to $150 \mathrm{~m}$ of $\log \left(b_{\mathrm{bp}}(555)\right)$. Source: Ocean Data View (sections Schlitzer, R., Ocean Data View, http://odv.awi.de, 2016).

different at OUTPACE than at BIOSOPE (Fig. 11). These good relations obtained even in the UV domain, where Chl $a$ though absorbing at $380 \mathrm{~nm}$ does not show any absorption peak in the UV domain, were already observed in the southeastern Pacific during the BIOSOPE cruise, for equivalent ranges and attributed to the fact that $\mathrm{CDM}$ substances absorbing in the UV domain co-vary with Chl $a$ (Tedetti et al., 2010). The reason why the relationships are different at 305 and $325 \mathrm{~nm}$ wavelengths but not other UV bands (e.g., $340,380 \mathrm{~nm}$ ) is probably related to the presence of Trichodesmium and other constituent co-varying with $\mathrm{Chl}$ and absorbing more at 305 and $325 \mathrm{~nm}$ than at longer UV wavelengths. It can be noted, for the same $\mathrm{Chl} a$, that ratios are higher at OUTPACE than at BIOSOPE; that is, absorption would be lower in the 305 and $325 \mathrm{~nm}$ bands and this difference is stronger at high $\mathrm{Chl} a$ (rich stations in the upwelling at BIOSOPE, MA stations and LDB at OUTPACE). One possible reason is that CDOM and CDM may be higher in the coastal upwelling or Marquesas Islands waters than in the Trichodesmium-rich waters of OUTPACE.

\subsection{Influence of Trichodesmium on the distribution of UV-visible $\mathbf{n L}_{\mathbf{w}}(\lambda)$}

To better assess the influence of Trichodesmium on the distribution of $\mathrm{nL}_{\mathrm{w}}(\lambda)$ values, the eight radiances measured during the southwestern Pacific OUTPACE cruise (this study) and the southeastern Pacific BIOSOPE cruise (2004) were statistically analyzed and compared. Figure $12 \mathrm{a}-\mathrm{d}$ show the results of a PCA operated separately on $\mathrm{nL}_{\mathrm{w}}(\lambda)$ values and TChl $a$ concentrations for the two cruises. In the western tropical South Pacific (OUTPACE), the first two principal components (PCs) represent $94 \%$ of total variance (Fig. 12b). The graph of correlations between PCs and the variables (Fig. 12a) indicates that $\mathrm{UV}$ and visible $\mathrm{nL}_{\mathrm{w}}(\lambda)$ are distributed along the PC1 axis, with all radiances on the right side, except $565 \mathrm{~nm}$. This first axis (81\% of total variance) indicates an effect of Chl $a$ on $\mathrm{nL}_{\mathrm{w}}(\lambda)$, with all $\mathrm{nL}_{\mathrm{w}}(\lambda)$ being higher at low $\mathrm{Chl} a$ (blue waters) and lower at high Chl $a$ (mesotrophic waters), except at $565 \mathrm{~nm}$, where on the contrary $\mathrm{nL}_{\mathrm{w}}$ increases with $\mathrm{Chl} a$. Oligotrophic stations are on the right side and mesotrophic stations on the left. PC2 represents $13 \%$ of the total variance. The variables that have significant correlation with PC2 are $\mathrm{nL}_{\mathrm{w}}(565)$ (Chl $a$-rich wa- 
(a)

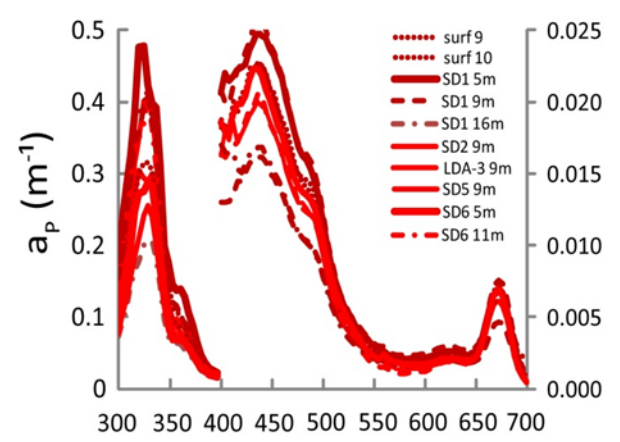

(b)

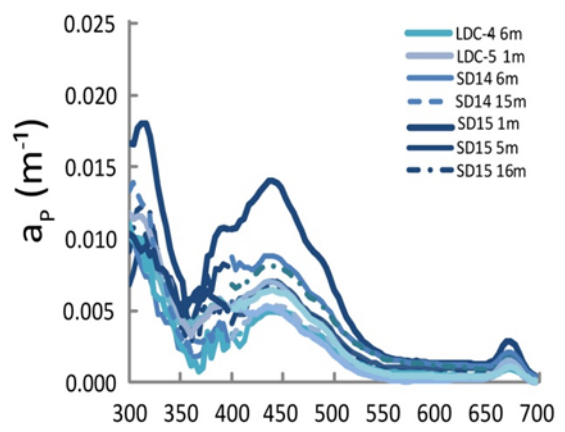

Wavelength $(\mathrm{nm})$

(c)

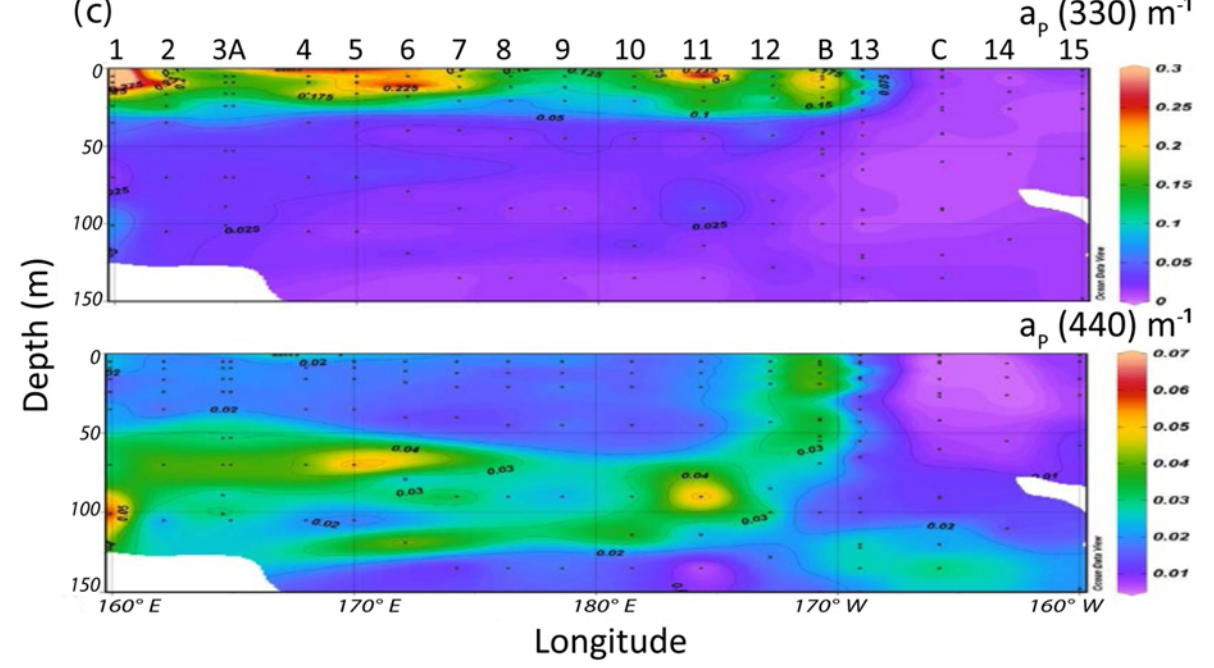

Figure 9. IOPs (continued): (a) in situ absorption spectrum of Trichodesmium-rich waters as measured by the filter technique showing MAA absorption (on frozen filters) at 330 and $360 \mathrm{~nm}$. Note the two different axes for $330 \mathrm{~nm}$ (left $y$ axis) and for $440 \mathrm{~nm}$ (right $y$ axis) and (b) idem for Trichodesmium-poor waters (only one $y$ axis), (c) OUTPACE section of $a_{P}(330)$ (upper panel) and $a_{P}(440)$ (lower panel). Source: Ocean Data View (sections Schlitzer, R., Ocean Data View, http://odv.awi.de, 2016).

ters) and $\mathrm{nL}_{\mathrm{w}}$ (490) (Chl $a$-poor waters), both on the upper side of the PC2 axis. These different behaviors in $\mathrm{nL}_{\mathrm{w}}(565)$ and $\mathrm{nL}_{\mathrm{w}}(490)$ are significant compared to the sensitivity of the Satlantic instrument. A series of stations are positively linked to this PC2 axis (LDB4, SD1, SD2, LDA-2, SD7) while LDA-3 and LDA-4 are negatively linked to PC2. The relatively high correlation between $\mathrm{PC} 2$ and $\mathrm{nL}_{\mathrm{w}}(565)$, minimally influenced by $\mathrm{Chl} a$, suggests that parameters other than abundance (e.g., size, type) might affect $\mathrm{nL}_{\mathrm{w}}(565)$ at the stations with sizeable PC2 values. In comparison, the first two PCs for the southeastern Pacific dataset (BIOSOPE) represent $96 \%$ of the total variance, with $89 \%$ for $\mathrm{PC} 1$ and only $7 \%$ for $\mathrm{PC} 2$ (Fig. 12c). The main difference is that $\mathrm{nL}_{\mathrm{w}}(565)$ is no longer linked to PC2, only to PC1, and that for PC2 $\mathrm{nL}_{\mathrm{w}}(490)$ has an opposite behavior to that in the southwestern Pacific (correlation is negative instead of positive). At $490 \mathrm{~nm}$, Chl $a$ appears to explain most of the $\mathrm{nL}_{\mathrm{w}}$ variability. This could reflect the absence of Trichodesmium in the east- ern Pacific. Except for a few stations, the PC2 contribution is much lower; that is, variability is mostly described by PC1.

\section{Discussion}

\subsection{Contribution of other phytoplankton and filamentous cyanobacteria to optical properties for interpreting satellite $\mathrm{Chl} a$ imagery}

The determination of Trichodesmium's influence on IOPs compared to other microorganisms and non-living particles in the sea is a main challenge. Indeed, previous models showed that absorption is governed by size and intracellular content (Bricaud et al., 1995, 2004, 2010) and that the absorption by large Trichodesmium colonies suffers from a double package effect (in filaments and in colony; Subramaniam et al., 1999a, b; Dupouy et al., 2008). Absorption by MAAs was observed on disaggregated colonies rather than on intact 


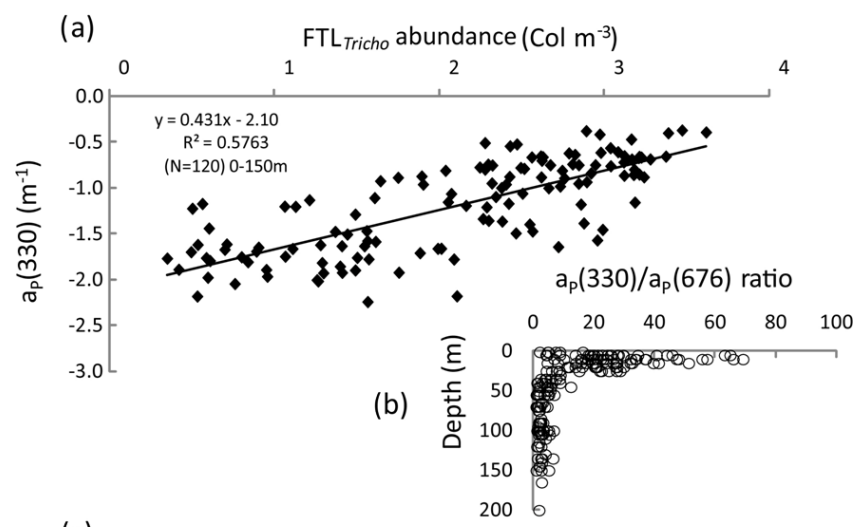

(c)

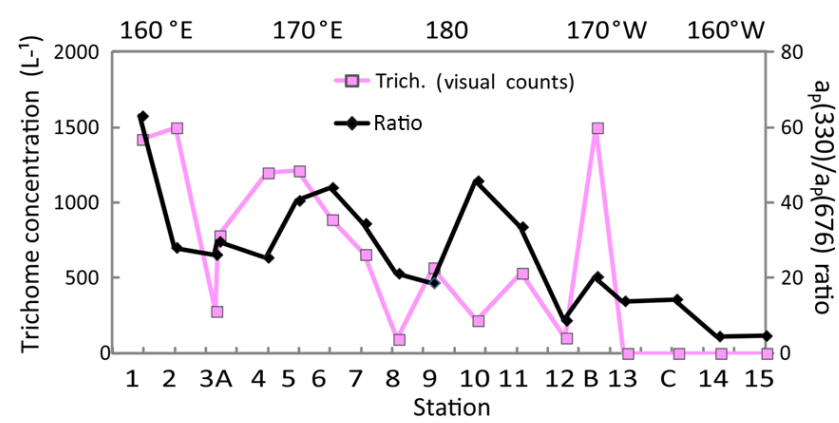

Figure 10. IOPs (continued): (a) relationship (log-log) between

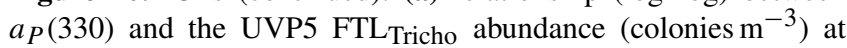
all stations and depths $(0-150 \mathrm{~m})$. (b) Vertical distributions of $a_{P}(330) / a_{P}(676)$ at all stations, (c) OUTPACE surface values of the ratio $a_{P}(330) / a_{P}(676)$ and trichome concentration (visual counts) along the transect. The $x$ axis represents the station numbers (below) and the main longitudes (above).

colonies (Fig. 3 in Subramaniam et al., 1999a), suggesting that a large fraction of MAAs is potentially present in sheaths or in the intracolony spaces. It has been shown that the highest $a_{P}(330)$ values in the upper layer, particularly in the western part of the MA, coincided with the highest FTL Tricho (for all stations) and that the correlation was significant $\left(r^{2}=\right.$ $0.55, n=120, p<0.0001)$. Conversely, there was no cor-

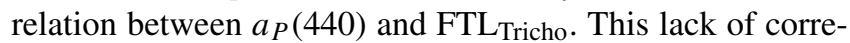
lation is striking as Trichodesmium contribution to TChl $a$ is between $30 \%$ and $60 \%$ along the transect and somehow contradicts the good correlation between phytoplankton absorption coefficient at $440 \mathrm{~nm}$ and TChl $a$ of colonies concentrated in tanks (Dupouy et al., 2008). TChl $a$ measured from HPLC large volumes $(4.5 \mathrm{~L})$ or $a_{P}(440)(2.5 \mathrm{~L})$ catches at a maximum one large $\mathrm{FTL}_{\text {Tricho. }}$. Indeed, in order to get a representative Trichodesmium biomass or $a_{P}(440)$, it would be necessary to adjust filtered volumes to expected abundance (8 L, Tenório et al., 2018). This is not the case for $a_{P}(330)$ or $a_{P}(360)$ peaks, which are both sensitive to the presence of colonies on the filter and are therefore the best indicators of Trichodesmium abundance. It must also be noted that the high package effect of absorption by Trichodesmium colonies
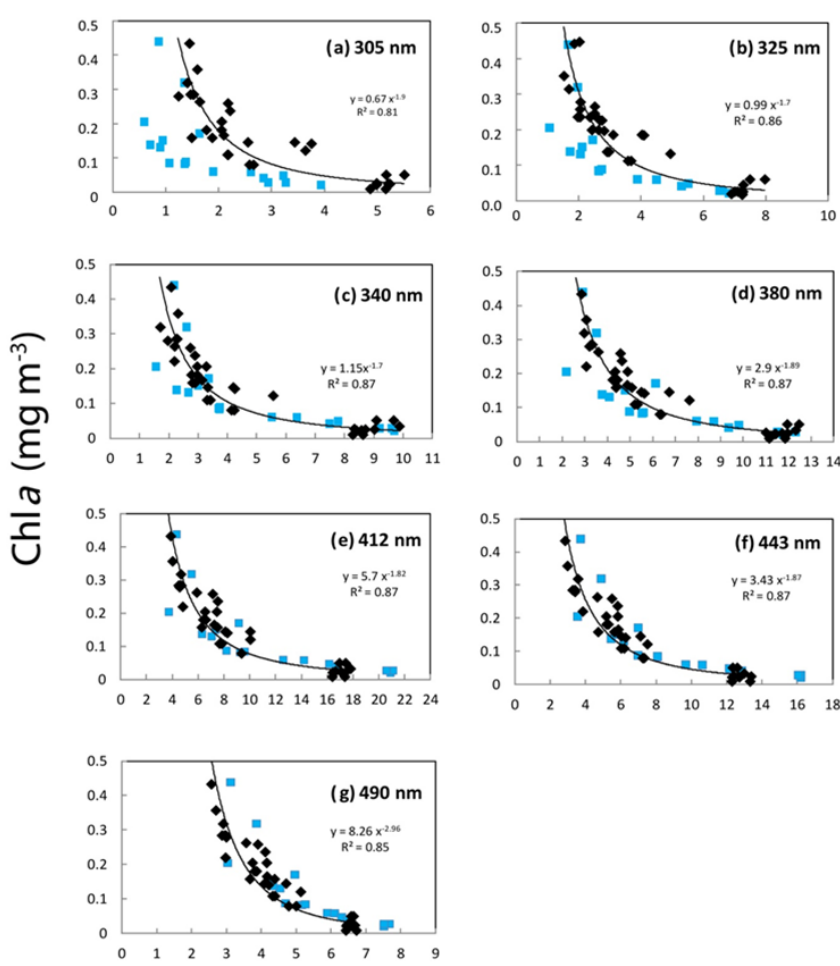

$\mathrm{nLw} / \mathrm{nLw} 565 \mathrm{~nm}$

Figure 11. Correlations between the Chl $a$ (fluorimetry) and the ratio of $\mathrm{nL}_{\mathrm{W}}(\lambda) / \mathrm{nL}_{\mathrm{W}}(565 \mathrm{~nm})$ at different $\mathrm{UV}$ and visible wavelengths. Equations and determination coefficient $\left(r^{2}\right)$ of the power law are indicated for each wavelength: (a) 305, (b) 325, (c) 340, (d) 380 , (e) 412 , (f) 443 and (g) $490 \mathrm{~nm}$. All stations of the OUTPACE (in black) and BIOSOPE (in blue) transect are included.

due to a double shadow effect of absorption of light inside the filament, and because of the stacking in a colony (Subramaniam et al., 1999a, b; McKinna, 2015), tends to lower the specific absorption $a_{P}(440)$. Similarly, it was also striking that the in situ red fluorescence signal in the upper layer at OUTPACE is weak as already found on CTD profiles in the region despite a large abundance of FTL Tricho (DIAPALIS; Tenório et al., 2018). This can be attributed to a low red fluorescence of colonies in the upper layer. Also, the small volume $(0.25 \mathrm{~mL}$; Neveux et al., 2010) "seen" by the ECO FLNTU fluorometer of the CTD does not contain many colonies, and the response of large colonies to the blue excitation light is low comparatively to one of the numerous small picoplanktonic cells. Such low responses in absorption and fluorescence could lead to an underestimate of the biomass of Trichodesmium from optical remote sensing.

Backscattering in the ocean is influenced by small particles $(<0.5 \mu \mathrm{m})$ of mineral origin, bubbles and colloids rather than by marine living particles (Loisel et al., 2007; Stramski et al., 2008) but also by large Trichodesmium colonies or associated detritus (Dupouy et al., 2008). Recent studies in the open ocean indicate a greater contribution of phytoplankton- 
PCA-OUTPACE
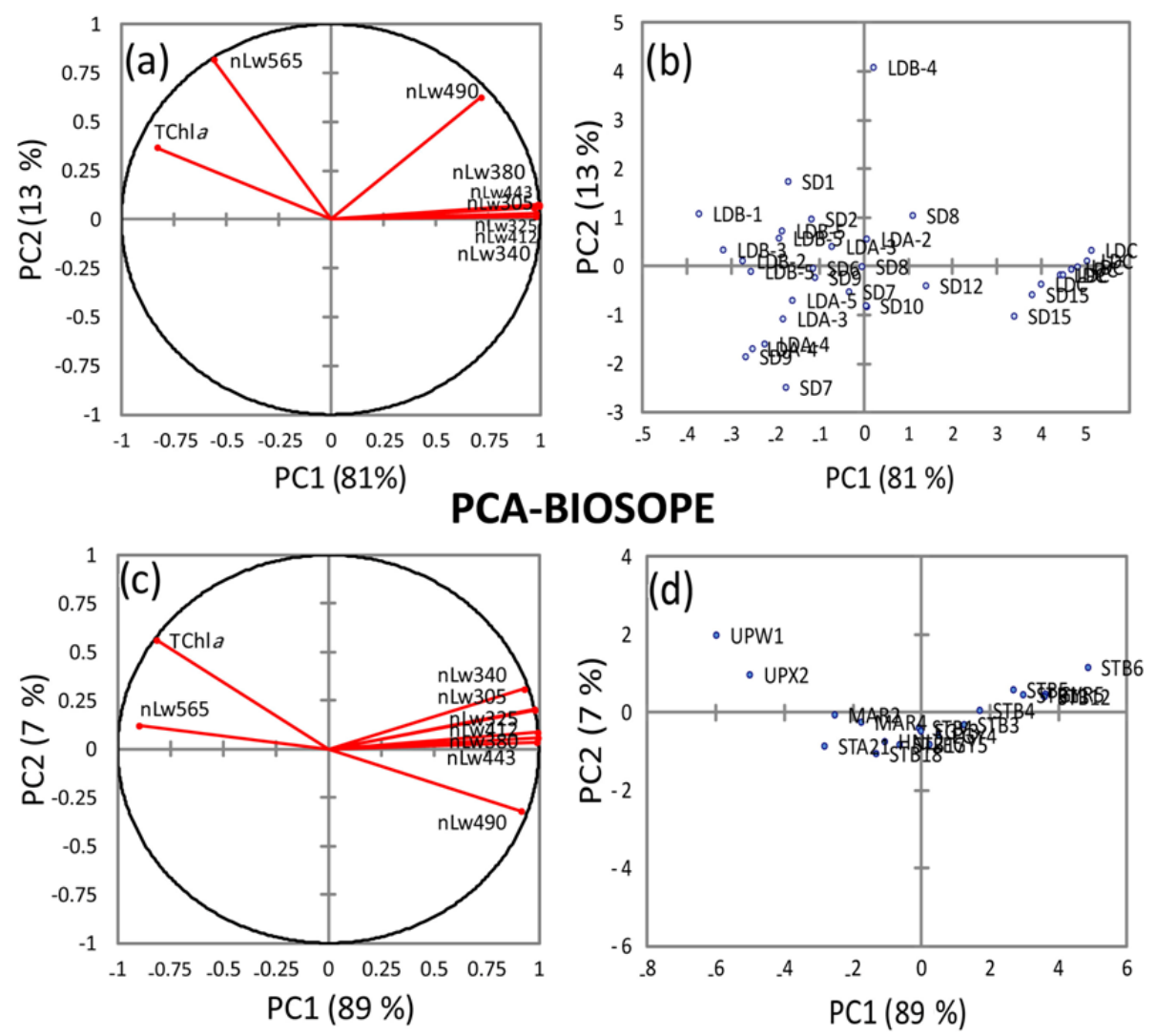

Figure 12. Principal component analysis (PCA), based on Pearson's correlation matrices, computed on the $\mathrm{nL}_{\mathrm{w}}(\lambda)$ and TChl $a$ for OUTPACE (a, b) and for BIOSOPE (c, d). For OUTPACE (a, b) all surface data were used, including 7 days at LDA, LDB and LDC ( $n=37)$. For BIOSOPE, all surface data $(n=17)$ were used $(\mathbf{c}, \mathbf{d})$. Correlation circle (left panels), projection of stations on the first factorial planes (F1 and F2) (right panels).

sized particles to $b_{\mathrm{bp}}$ than theoretically predicted (Dall'Olmo et al., 2009; Brewin et al., 2012; Martinez-Vicente et al., 2013; Slade and Boss, 2015). In oligotrophic waters of the southeastern Pacific, absorption and backscattering coefficients are well related to TChl $a$ with specific relationships (Morel et al., 2007; Huot et al., 2008; Bricaud et al., 2010). At $5 \mathrm{~m}$ depth, the OUTPACE H6-backscattering data $\left(b_{\mathrm{bp}}(550)\right)$ were, on average for all stations, 2 times higher than the $b_{\mathrm{bp}}(550)$ calculated from TChl $a$ from the equation $b_{\mathrm{bp}}=\sigma[\mathrm{Chl}] \beta$ during the BIOSOPE cruise (Huot et al., 2008; Stramski et al., 2008). The particulate backscattering was enhanced in the presence of Trichodesmium with a value 2 to 5 times higher at $5 \mathrm{~m}$ than at $25 \mathrm{~m}$ depth with high Chlspecific backscattering coefficients $\left(0.006\right.$ to $0.016 \mathrm{~m}^{2}(\mathrm{mg}$ TChl $a)^{-1}$ ) and low backscattering slopes (as already shown in tanks; Dupouy et al., 2008). Nevertheless, the layer of the highest backscattering coefficient is situated above the $10 \mathrm{~m}$ $\mathrm{FTL}_{\text {Tricho, }}$, and no relationship was found between vertical distributions of $b_{\mathrm{bp}}$ and FTL Tricho, at least in the MA (SD1SD6, LDA).

\subsection{Contribution of Trichodesmium spp. to TChl a}

All Trichodesmium abundance data, obtained from UVP5, pigments and flow cytometry data, or from visual counts showed the highest abundance in the western part of the MA and the lowest abundance in the SPG, with a high value at LDB. Trichome abundances estimated from pigment algorithms were in the same range as those enumerated by microscopy in the region (at $167^{\circ} \mathrm{E}, 21^{\circ} \mathrm{S}$, DIAPALIS data; Tenório et al., 2018). The UVP5 counted the largest colonies of the Trichodesmium population, i.e., the upper part of the colony size distribution. The factor between UVP5-FTL $\mathrm{Tricho}_{\text {Tri }}$ and trichome concentrations visual counts depends on the number of isolated filaments, small colonies and on the number of trichomes per colony; this was defined as an "aggregation factor (AF)". This AF determined when using video recorders on Trichodesmium colonies varied between 400 for the highest to 50 for the lowest (Davis and McGillicudy, 2006; Guidi et al., 2012; Olson et al., 2015). The larger AF found here implies that the FTL Tricho represents a smaller proportion of total trichomes in the western tropical South 
Pacific than during other cruises or in other regions. The vertical distributions of UVP5-FTL ${ }_{\text {Tricho }}$ and trichome concentration show that Trichodesmium populations of both sizes were concentrated below 0 and $30 \mathrm{~m}$ and scarce below $50 \mathrm{~m}$, which contrasts with the Trichodesmium distribution inferred from the nifH gene still detected below $100 \mathrm{~m}$ (Stenegren et al., 2018). In the western tropical South Pacific, trichomes are generally found from 0 to $60 \mathrm{~m}$ (Tenório et al., 2018; Carpenter, unpublished data; Trichonesia 1 in 1998 cruise), the maximum abundance being found between 5 and $10 \mathrm{~m}$ depth, with a regular decrease of colonies from 5-15 to $60 \mathrm{~m}$ depth. Around $180^{\circ} \mathrm{E}$, Trichodesmium colonies were located deeper than in the Melanesian region. Nevertheless, there might be enough colonies below $20 \mathrm{~m}$ (less visible by the satellite) to produce mats episodically, when environmental conditions are favorable, as it was often observed south of Fiji with the CZCS ocean color sensor (Dupouy et al., 1992). On this cruise, visual counts could not detect deep green Trichodesmium colonies as those detected in the Coral Sea at $150^{\circ} \mathrm{E}$ (Neveux et al., 2006).

Apart from Trichodesmium, Proc was the other dominant group impacting the $\mathrm{Chl} a$ biomass in two parts of the WTSP ocean: (1) the western part of the MA between New Caledonia and Vanuatu, also impacted by a large contribution of Trichodesmium, and (2) the eastern part of the transect (FI) which was more oligotrophic. LDB showed a dominance of both Trichodesmium and Proc, with TChl $a$ proportions of Trichodesmium, Syn + Peuk, Microeuk, Neuk, and Proc of $25,7,1.4,5$ and $45 \%$, respectively.

\subsection{The influence of Trichodesmium-CDM on UV-visible water-leaving radiance}

OUTPACE and BIOSOPE data show that the southwestern and southeastern Pacific surface waters exhibited similar ranges of values for $\mathrm{nL}_{\mathrm{w}}(\lambda)$ and Chl $a(0.02-0.58$ and $0.02-$ $1.3 \mathrm{mg} \mathrm{m}^{-3}$, respectively). Apart from the "extreme" value of $1.3 \mathrm{mg} \mathrm{m}^{-3}$ recorded in the Peru upwelling (BIOSOPE), Chl $a$ ranges were similar during the two cruises. The fact that $\mathrm{nL}_{\mathrm{w}}$ ratios were well related to TChl $a$ in the UV domain as well as in the visible domain shows that a strong coupling exists between the UV-absorbing material and Chl $a$. The contribution of chromophoric detrital matter $(\mathrm{CDM}=\mathrm{CDOM}+\mathrm{NAP})$ is the sum of the total colored detritus + dissolved absorption (Bricaud et al., 2010). During OUTPACE, a high CDOM amount was associated with Trichodesmium through the formation of CDOM (mainly MAAs) from the colony (Subramaniam et al., 1999a; Steinberg et al., 2004; Dupouy et al., 2008). MAAs identified by their strong UV absorption at 332 and $362 \mathrm{~nm}$ are mainly asterina-330 and shinorine, but also minor quantities of mycosporine-glycine, porphyra-334 and palythene-360; all are present in Trichodesmium (Carreto et al. in Roy et al., 2011). A complete analysis of the different components of CDM implies the determination of NAP after bleaching of the filters (Bricaud et al., 2010), but this is biased because of the incomplete degradation of phycoerythrins in the case of high cyanobacterial abundance. Note that the MAA absorption of live colonies is much lower than that of the frozen ones (Dupouy et al., 2008); therefore its impact is much lower on in situ $\mathrm{nL}_{\mathrm{w}}$ values, OUTPACE and BIOSOPE data differing only in two spectral bands, the yellow-green $\left(\mathrm{nL}_{\mathrm{w}}(565)\right)$ and the blue-green $\left(\mathrm{nL}_{\mathrm{w}}(490)\right)$, according to PCA results. The PC1 axis was linked to Chl $a$ concentration for both cruises while the PC2 was linked to another optically active variable, independent of $\mathrm{Chl} a$, especially for OUTPACE. The PCA shows that during OUTPACE a significant correlation exists between PC2 and $\mathrm{nLw}$ (490) and $\mathrm{nLw}$ (565). The fact that the relationship with PC2 is weaker in the southeastern Pacific (and the PC2 contribution about twice smaller) means that these other optical components had little influence during the BIOSOPE cruise - there is practically no effect of PE or particles at high Chl $a$ concentrations. Indeed, Huot et al. (2008) showed that backscattering measured during the BIOSOPE stations (between $41^{\circ}$ and $173^{\circ} \mathrm{W}$ ) was totally linked to Chl $a$. The relationship of $\mathrm{nL}_{\mathrm{w}}$ (490) to PC2 is more difficult to interpret due to its opposite behavior between the southwestern (OUTPACE) and the southeastern (BIOSOPE) Pacific. One explanation would be that, in the presence of Trichodesmium, a higher backscattering is expected at all wavelengths (linked to a factor other than $\mathrm{Chl} a$ ) and a PE fluorescence impacting $\mathrm{nL}_{\mathrm{w}}$ at $565 \mathrm{~nm}$. The fact that $\mathrm{nL}_{\mathrm{w}}(490)$ is not correlated to TChl $a$ in the same way as $\mathrm{nL}_{\mathrm{w}}(565)$ implies that the backscattering is not the only driving parameter and that another optical property impacts $\mathrm{nL}_{\mathrm{w}}(490)$. This could be the absorption effect by zeaxanthin (the major photoprotecting pigment, not totally correlated with $\mathrm{Chl} a$ as shown by the PCA) or by a different accessory pigment. The signification of PC2 was explored by performing a new PCA using phytoplankton group index (micro-, nano- and pico-) as additional variables, as well as other parameters $\left(a_{P}(330)\right.$ and $a_{P}(565)$, PE $>10 \mu \mathrm{m}$, UVP5-FTL $_{\text {Tricho }}$ and zeaxanthin). New PC1 and $\mathrm{PC} 2$ axes explain $47 \%$ and $18 \%$ of total variance, respectively. $\mathrm{PC} 1$ is still linked to TChl $a$. PC2 represents the gradient between the stations influenced by cyanobacteria and those rich in micro- and nano-phytoplankton. The relationship between $\mathrm{PC} 2$ and cyanobacteria (rich in $\mathrm{Chl} b$ or/and DV-Chl $b$ and zeaxanthin) was inverse to that with the other groups (micro-, nano-phytoplankton). At BIOSOPE, where $\mathrm{nL}_{\mathrm{w}}(490)$ is essentially a function of Chl $a$, PC2, the zeaxanthin effect would be negligible or totally linked with the one of Chl $a$. Our PCA indicated that the two wavelengths (490 and $565 \mathrm{~nm}$ ) showed anomalous behavior. The latter were chosen by Westberry et al. (2005) to set an algorithm to globally map Trichodesmium high abundance with SeaWiFS satellite data. The modeled spectrum of a Trichodesmium bloom at equivalent $\mathrm{Chl} a$ concentrations to those recorded in that study ( $0.5 \mathrm{mg} \mathrm{Chl} a \mathrm{~m}^{-3}$ ) showed higher magnitudes for $\mathrm{nL}_{\mathrm{w}}(490), \mathrm{nL}_{\mathrm{w}}(510)$ and $\mathrm{nL}_{\mathrm{w}}(565)$ (Subramaniam et al., 
1999 b) with a $\mathrm{nL}_{\mathrm{w}}(510)$ greater than $\mathrm{nL}_{\mathrm{w}}(443)$. Moreover, the authors pointed out the difficulty of direct comparisons between modeled and measured UV-visible radiance due to the uncertainties in Chl $a$ measurements or Trichodesmium abundance. Such spectral responses were not obtained at OUTPACE. This may explain why the model did not provide satisfactory results when applied around WTSP islands (Westberry and Siegel, 2006), where blooms are numerous as detected by TRICHOSAT particularly in summer (Dupouy et al., 2011). The reason might be that the radiance anomalies at 490 and $565 \mathrm{~nm}$ are different than expected versus TChl $a$ or Trichodesmium concentrations, and particularly in the case of moderate abundance.

\section{Conclusions}

The OUTPACE cruise in the WTSP from $158^{\circ} \mathrm{E}$ to $160^{\circ} \mathrm{W}$ provided a unique set of simultaneous measurements of $\mathrm{nL}_{w}(\lambda)$ in the UV and visible domains, pigments and Trichodesmium and picoplanktonic cell abundance along the whole transect during a late summer bloom. Trichodesmium

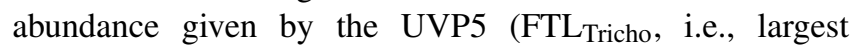
colonies) with an AF of 500-700 with trichome concentration by different methods decreased from west to east and occupied the $50 \mathrm{~m}$ upper layer of the ocean from the MA to the FI. Such an AF between large colonies and trichome concentration is indicative of aggregation processes and is specific to all cameras towered or lowered in the ocean. Trichodesmium abundance was also well correlated with the absorption peak of MAAs, i.e., $a_{P}(330)$ and the photoprotection index $\left(a_{P}(330) / a_{P}(676)\right)$, useful parameters to quantify the latter. The weak CTD-Chl $a$ fluorescence and blue absorption observed in rich Trichodesmium waters tend to underestimate Prochlorococcus abundance if used on profilers or ocean color remote sensing while carrying out the backscattering (high coefficient, spectral troughs) trace surface aggregations. Along the $165^{\circ} \mathrm{E}-170^{\circ} \mathrm{W}$ transect, Trichodesmium together with Prochlorococcus represented the major part of TChl $a$ (a mean of $40 \%$ for the whole transect at the surface, as the other groups were negligible). Trichodesmium contribution to TChl $a$ was the highest $(60 \% \mathrm{TChl} a)$ in the western part of the Melanesian archipelago (around New Caledonia and Vanuatu) and regularly decreased to the east, in the vicinity of the islands of Fiji, to reach a minimum in the South Pacific Gyre stations, where the Prochlorococcus contribution to TChl $a$ was higher. Profiling Trichodesmium abundance from 0 to $150 \mathrm{~m}$ with a UVP5 allowed the detection of colonies deeper south of Fiji, which may produce mats more episodically than at $170^{\circ} \mathrm{E}$. In the WTSP, the relationship between $\mathrm{nL}_{\mathrm{w}}$ and $\mathrm{Chl} a$ was generally similar to that found in the eastern tropical Pacific. In particular, radiance ratios were related to TChl $a$ in the visible, and the UV domain was interpreted as a strong coupling between the UV-absorbing CDM and Chl $a$. The
$\mathrm{nL}_{\mathrm{w}}$ values were strongly correlated to $\mathrm{Chl} a$ except in the greenish blue and yellowish green (490 and $565 \mathrm{~nm}$ ). These results, as well as differences in the PCA of BIOSOPE data, suggested that $\mathrm{nL}_{\mathrm{w}}$ variability in the WTSP was influenced by other variables associated with Trichodesmium presence, namely a high specific backscattering coefficient, phycoerythrin fluorescence, and/or zeaxanthin absorption (related to phytoplankton group size). These wavelengths (490 and $565 \mathrm{~nm}$ ) are often chosen in Trichodesmium detection algorithms. While detecting Trichodesmium mats (above surface) with the "red edge" is possible with MODIS (Rousset et al., 2018), the change in the UV-visible radiance detected during OUTPACE at moderate Trichodesmium concentrations is essential to assess true nitrogen fixation rates in the WTSP as it addresses the general case where colonies are homogeneously distributed over the first optical depth. The use of a hyperspectral profiler to better define the radiance changes linked to Trichodesmium and the development of an instrument to detect the whole Trichodesmium population, including smaller colonies or isolated trichomes, are both required. 


\section{Appendix A: AOP measurements and processing}

For in-water sensors, the full width at half maximum (FWHM) of the channels was $2 \mathrm{~nm}$ for 305,325 and $340 \mathrm{~nm}$, and $10 \mathrm{~nm}$ for 380, 412, 443, 490 and $565 \mathrm{~nm}$. For in-air sensors, the FWHM of the channels was $2 \mathrm{~nm}$ for 305,325 and $340 \mathrm{~nm}, 10 \mathrm{~nm}$ for $380 \mathrm{~nm}$, and $20 \mathrm{~nm}$ for 412, 443, 490 and $565 \mathrm{~nm}$. The MicroPro free-fall profiler was operated from the rear of the ship and deployed 20-30 $\mathrm{m}$ away to minimize the shadowing effects and disturbances of the ship. Surface irradiance $\left(E_{\mathrm{S}}(\lambda)\right.$, in $\left.\mu \mathrm{W} \mathrm{cm}{ }^{-2}\right)$, which is equivalent to the downward irradiance just above the sea surface, $\left(E_{\mathrm{d}}(0+, \lambda)\right)$, was simultaneously measured at the same channels on the ship deck using other OCR-504 sensors to account for the variations of cloud conditions during the cast. Details of cast measurements are as follows. Rejection was the case at SD6 (second profile), during the long-duration stations LDC (second profile day 1 , second profile day 2 , first profile day 3 , second profile day 5) and LDA (first profile day 5), LDB (second profile day 3) an LDC (second profile day 1, second profile day 2 , second profile day 5). In total, all stations were characterized by at least one to two profiles and sometimes three profiles. Only two values of $\mathrm{nL}_{\mathrm{w}}(\lambda)$ at $305 \mathrm{~nm}$ (SD5 and SD14) showed some suspicious radiometric values among the $30 \mathrm{~nL}_{\mathrm{w}}$ profiles.

$E_{\mathrm{d}}(\lambda)$ was taken from the OCR HyperPro values from 400 to $700 \mathrm{~nm}$ and then integrated using the formula (Tedetti et al., 2007, Eq. 1) where $E_{\mathrm{d}}, \operatorname{PAR}(Z)$ is the downward irradiance in the spectral range of PAR at depth $Z$ (quanta $\mathrm{cm}^{-2} \mathrm{~s}^{-1}$ ), $\lambda$ is the wavelength $(\mathrm{nm}), h$ is the Planck constant $\left(6.63 .10^{-34} \mathrm{~J} . \mathrm{s}\right), c$ is the speed of light in the vacuum $\left(3.108 \mathrm{~ms}^{-1}\right)$ and $E_{\mathrm{d}}(Z, \lambda)$ is the downward irradiance at depth $Z$ (in $\mu \mathrm{W} \mathrm{cm}{ }^{-2}$ ). Downward attenuation coefficient was determined in accordance with their Eq. (2), where $E_{\mathrm{d}}(0-, \lambda)$ is the downward irradiance beneath the surface. Because of the wave-focusing effects leading to fluctuations in in-water irradiance near the surface, irradiance data of the first meters were omitted from the calculation, and $E_{\mathrm{d}}(0-, \lambda)$ was theoretically computed from deck measurements as in their Eq. (3), where $\alpha(0.043)$ is the Fresnel reflection albedo for irradiance from sun and sky. The diffuse attenuation coefficient for upward irradiance was determined from the slope of the linear regression of the logtransformed upward radiance versus depth in accordance with the equation between $L_{\mathrm{u}}\left(Z_{1}, \lambda\right)$ and the upward radiance $L_{\mathrm{u}}\left(Z_{2}, \lambda\right)\left(\mu \mathrm{W} \mathrm{cm}{ }^{-2} \mathrm{sr}^{-1}\right]$ at depths $Z_{1}$ and $Z_{2}(\mathrm{~m})$, respectively (Tedetti et al., 2010). As for $K_{\mathrm{d}}(\lambda)$, the depth interval within the upper water column used for the $K_{L}(\lambda)$ determination was chosen from a visual examination of each log-transformed profile and was typically $10,15,20$, or $30 \mathrm{~m}$, depending on the stations and wave bands. The determination coefficients $\left(r^{2}\right)$ of the $K_{L}(\lambda)$ calculation were $>0.98$. Water-leaving radiance $L_{\mathrm{W}}(\lambda)$ in $\mu \mathrm{W} \mathrm{cm}{ }^{-2} \mathrm{sr}^{-1}$ was then derived (their Eq. 2) where $L_{\mathrm{u}}(0-, \lambda)$ is the upward radiance beneath the sea surface computed by extrapolating $L_{u}(Z, \lambda)$ to the sea surface from $\mathrm{K}_{L}(\lambda)$ and Eq. (1), $t$ (0.975) is the upward Fresnel transmittance of the air-sea interface, and $n$ (1.34) is the refractive index of water. Normalized waterleaving radiance $\left(\mathrm{nL}_{\mathrm{W}}(\lambda)\right.$ in $\left.\mu \mathrm{W} \mathrm{cm}{ }^{-2} \mathrm{sr}^{-1}\right)$ was determined (equation 3 in Tedetti et al., 2010) by dividing the waterleaving radiance $L_{\mathrm{W}}(\lambda)$ by $E_{\mathrm{S}}(\lambda)$ the surface irradiance and multiplying by $F_{0}(\lambda)$ the solar irradiance at the top of the atmosphere, at the mean Earth-Sun distance $\left(\mu \mathrm{W} \mathrm{cm}^{-2}\right)$. $F_{0}(\lambda)$ data in the ranges $305-340$ and $380-565 \mathrm{~nm}$ were used from Thuillier et al. (1997, 1998) as in Tedetti et al. (2010). 
Data availability. All data and metadata are available at the French INSU/CNRS LEFE CYBER database (scientific coordinator: Herveéé Claustre; data manager and webmaster: Catherine Schmechtig) at the following web address: http://www.obs-vlfr. fr/proof/php/outpace/outpace.php (last access: 20 August 2018) (INSU/CNRS LEFE CYBER, 2017).

Author contributions. $\mathrm{CD}$ and RF acquired optical and pigment measurements aboard the R/V L'Atalante during the OUTPACE cruise and were responsible for the analysis of the data and elaboration of the manuscript. MM, BC and MT processed the SATLANTIC UV-Vis data and helped in the use of statistics tests. MP acquired and processed the UVP5 data aboard the R/V L'Atalante during the OUTPACE cruise, and LG and FL helped in analyzing the data. JN provided methods for extracting Chl $a$ and zeaxanthin contributions of Trichodesmium. SD acquired the flow cytometry aboard the R/V L'Atalante during the OUTPACE cruise. RS supervised the use of the SATLANTIC UV-Vis radiometer. MR provided phycoerythrin data and ensured high-quality figures. All authors greatly improved the manuscript.

Competing interests. The authors declare that they have no conflict of interest.

Special issue statement. This article is part of the special issue "Interactions between planktonic organisms and biogeochemical cycles across trophic and $\mathrm{N}_{2}$ fixation gradients in the western tropical South Pacific Ocean: a multidisciplinary approach (OUTPACE experiment)". It is not associated with a conference.

Acknowledgements. We thank Joséphine Ras, Laboratoire d'Océanologie de Villefranche, and Crystal Thomas, NASA Goddard Space Flight Center, for performing the HPLC analysis, Mireille Pujo-Pay for scientific advice during the cruise, Benjamin Blanc for sorting and validating UPV-5 images, David Varillon, IRD US IMAGO for invaluable technical support, Philippe Gérard (MIO) for Chl $a$ analyses, and the administrative staff of the IRD Center of Nouméa. We thank Rüdiger Röttgers (Helmholtz-Centrum Geesthacht) for helpful discussions during the elaboration of the manuscript. This is a contribution of the OUTPACE (Oligotrophy from Ultra-oligoTrophy PACific Experiment) project (https://OUTPACE.mio.univ-amu.fr/, last access: 20 August 2018) funded by the French National Research Agency (ANR-14-CE01-0007-01), the LEFECyBER program (CNRS-INSU), the GOPS program (IRD) and the Centre National d'Etudes Spatiales (BC T23, ZBC 4500048836). The OUTPACE cruise (https://doi.org/10.17600/15000900) was managed by MIO Institute from Marseille (France). The National Science Foundation supported Sophie Duhamel under grant OCE-1434916. The National Aeronautics and Space Administration supported Robert Frouin under various grants. Finally, we thank the two anonymous reviewers for their useful and constructive comments.

Edited by: Thierry Moutin

Reviewed by: two anonymous referees

\section{References}

Biegala, I. C., Aucan, J., Desnues, A., Rodier, M., Dupouy, C., Raimbault, P., Douillet, P., Hunt, B., Pagano, M., ClavereGraciette, A., Bonnefous, A., Roumagnac, M., Gasol, J., Periot, M., Schenkels, O., Sharma, P., Harlay, J., Eldin, G., Cravatte, S., Marin, F., Varillon, D., Roubaud, F., Jamet, L., Gérard, P., Goyaud, A., Legrand, H., Gouriou, Y., and Ganachaud, A.: The South Pacific Ocean Time Series (SPOT) station : a first focus on diazotrophs community, available at: http://www.eposters.net/poster/the-south-pacific-ocean-timeseries-spot-station-a-first-focus-on -diazotrophs-community (last access: 20 August 2018), 2014.

Blondeau-Patissier, D., Gower, J. F. R., Dekker, A. G., Phinn, S. R., and Brando, V. E.: A review of ocean color remote sensing methods and statistical techniques for the detection, mapping and analysis of phytoplankton blooms in coastal and open oceans, Prog. Oceanogr., 123, 123-144, 2014.

Bock, N., Van Wambeke, F., Dion, M., and Duhamel, S.: Microbial community structure in the western tropical South Pacific, Biogeosciences, 15, 3909-3925, https://doi.org/10.5194/bg-153909-2018, 2018.

Bonnet, S., Caffin, M., Berthelot, H., and Moutin, T.: Hot spot of $\mathrm{N}_{2}$ fixation in the western tropical South Pacific pleads for a spatial decoupling between $\mathrm{N}_{2}$ fixation and denitrification, Proc. Natl. Acad. Sci. USA, 114, E2800-E2801, https://doi.org/10.1073/pnas.1619514114, 2017.

Borstad, G. A., Gower, J., and Carpenter, E.: Development of algorithms for remote sensing of Trichodesmium blooms, in: Marine Pelagic Cyanobacteria: Trichodesmium and other Diazotrophs, 193-210, 1992.

Bracher, A., Bouman, H. A., Brewin, R. J. W., Bricaud, A., Brotas, V., Ciotti, A. M., Clementson, L., Devred, E., Di Cicco, A., Dutkiewicz, S., Hardman-Mountford, N. J., Hickman, A. E., Hieronymi, M., Hirata, T., Losa, S. N., Mouw, C. B., Organelli, E., Raitsos, D. E., Uitz, J., Vogt, M., and Wolanin, A.: Obtaining Phytoplankton Diversity from Ocean Color: A Scientific Roadmap for Future Development, Front. Mar. Sci., 4, 55, https://doi.org/10.3389/fmars, 2017.

Brewin, R. J. W., Hardman-Mountford, N. J., Lavender, S. J., Raitsos, D. E., Hirata, T., Uitz, J., Devred, E., Bricaud, A., Ciotti, A., and Gentili, B.: An inter-comparison of bio-optical techniques for detecting dominant phytoplankton size class from satellite remote sensing, Remote Sens. Environ. 115, 325-339, 2011.

Brewin, R. J. W., Dall'Olmo, G., Sathyendranath, S., and HardmanMountford, N. J.: Particle backscattering as a function of chlorophyll and phytoplankton size structure in the open-ocean, Opt. Express, 20, 17632-17652, 2012.

Bricaud, A., Babin, M., Morel, A., and Claustre H.: Variability in the chlorophyll-specific absorption coefficient of natural phytoplankton: analysis and parametrization, J. Geophys. Res., 100, 13321-13332, 1995.

Bricaud, A., Claustre, H., Ras, J., and Oubelkheir, K.: Natural variability of phytoplanktonic absorption in oceanic waters: Influence of the size structure of algal populations, J. Geophys. Res., 109, C11010, https://doi.org/10.1029/2009JC005517, 2004.

Bricaud, A., Babin, M., Claustre, H., Ras, J., and Tièche, F.: Light absorption properties and absorption budget of Southeast Pacific waters, J. Geophys. Res., 115, C08009, https://doi.org/10.1029/2009JC005517, 2010. 
Buitenhuis, E. T., Li, W. K. W., Vaulot, D., Lomas, M. W., Landry, M. R., Partensky, F., Karl, D. M., Ulloa, O., Campbell, L., Jacquet, S., Lantoine, F., Chavez, F., Macias, D., Gosselin, M., and McManus, G. B.: Picophytoplankton biomass distribution in the global ocean, Earth Syst. Sci. Data, 4, 37-46, https://doi.org/10.5194/essd-4-37-2012, 2012.

Capone, D. G., Zehr, J. P., Paerl, H. W., Bergman, B., and Carpenter, E. J.: Trichodesmium, a globally significant marine cyanobacterium, Science, 276, 1221-1229, 1997.

Carpenter, E. J., O’Neil, J. M., Dawson, R., Capone, D. G., Siddiqui, P. J., Roenneberg, T., and Bergman, B.: The tropical diazotrophic phytoplankter Trichodesmium: biological characteristics of two common species, Mar. Ecol. Progr. Ser., 95, 295-304, 1993.

Carpenter, E. J., Subramaniam, A., and Capone, D. G.: Biomass and primary productivity of the cyanobacterium Trichodesmium spp. in the tropical North Atlantic Ocean, Deep-Sea Res. Pt. I, 51, 173-203, 2004.

Carreto, J. I. and Carignan, M. O.: Mycosporine-like amino acids: relevant secondary metabolites, Chemical and ecological aspects, Mar. Drugs, 9, 387-446, 2011.

Dall'Olmo, G., Westberry, T. K., Behrenfeld, M. J., Boss, E., and Slade, W. H.: Significant contribution of large particles to optical backscattering in the open ocean, Biogeosciences, 6, 947-967, https://doi.org/10.5194/bg-6-947-2009, 2009.

Dandonneau, Y. and Gohin, F.: Meridional and seasonal variations of the sea surface chlorophyll concentration in the southwestern tropical Pacific (14 to $32^{\circ} \mathrm{S}, 160$ to $175^{\circ} \mathrm{E}$ ), Deep-Sea Res., 31 , 1377-1393, 1984.

Davis, C. S. and McGillicuddy Jr., D. J.: Transatlantic abundance of the $\mathrm{N}_{2}$-fixing colonial cyanobacterium Trichodesmium, Science, 312, 1517-1520, 2006.

De Boissieu, F., Menkes, C., Dupouy, C., Rodier, M., Bonnet, S., and Frouin, R.: Phytoplankton global mapping from space with a Support Vector Machine algorithm, 9261, 92611R, https://doi.org/10.1117/12.2083730, Proc. SPIE, 2014.

Dupouy, C., Petit, M., and Dandonneau, Y.: Satellite detected cyanobacteria bloom in the southwestern tropical Pacific. Implication for nitrogen fixation, Int. J. Remote Sens., 8, 389-396, 1988.

Dupouy, C.: La chlorophylle de surface observée par le satellite NIMBUS-7 dans une zone d'archipel (Nouvelle-Calédonie et Vanuatu): une première analyse, in : Halieutique, océanographie et télédétection: contribution française aux colloques francojaponais: thème: télédétection, edited by: Petit, M. and Stretta, J.-M., Bulletin de l'Institut Océanographique de Monaco, (spécial 6), 125-148, Colloque Scientifique Franco-Japonais; Colloque d'Océanographie, 5, 2., Tokyo; Shimizu (JPN), 1988/10/313, ISBN 2-7260-0142-4, 1990.

Dupouy, C.: Discoloured waters in the Melanesian archipelago (New Caledonia and Vanuatu), The value of the Nimbus-7 Coastal Zone Colour Scanner observations, in: Marine Pelagic Cyanobacteria: Trichodesmium and other diazotrophs, edited by: Carpenter, E. J., Capone, D. G., and Rueter, J. G., NATO ASI Series, C: Mathematical and Physical Sciences, vol. 362, Kluwer Academic Publishing, Dordrecht, Netherlands, 177-191, 1992.

Dupouy, C., Loisel, H., Neveux, J., Brown, S. L., Moulin, C., Blanchot, J., Le Bouteiller, A., and Landry, M. R.: Microbial absorption and backscattering coefficients from in situ and POLDER satellite data during an El Nino-Southern Oscillation cold phase in the equatorial Pacific $\left(180^{\circ}\right)$, J. Geophys. Res., 108, 8138, https://doi.org/10.1029/2001JC001298, 2003.

Dupouy, C., Neveux, J., Dirberg, G., Röttgers, R., Tenório, M. M. B., and Ouillon, S.: Bio-optical properties of the marine cyanobacteria Trichodesmium spp., J. Appl. Remote Sens., 2, 117, 2008.

Dupouy, C., Neveux, J., Ouillon, S., Frouin, R., Murakami, H., Hochard, S., and Dirberg, G.: Inherent optical properties and satellite retrieval of chlorophyll concentration in the lagoon and open ocean waters of New Caledonia, Mar. Pollut. Bull., 61, 503518, 2010.

Dupouy, C., Benielli-Gary, D., Neveux, J., Dandonneau, Y., and Westberry, T. K.: An algorithm for detecting Trichodesmium surface blooms in the South Western Tropical Pacific, Biogeosciences, 8, 3631-3647, https://doi.org/10.5194/bg-8-36312011, 2011.

Dutheil, C., Aumont, O., Gorguès, T., Lorrain, A., Bonnet, S., Rodier, M., Dupouy, C., Shiozaki, T., and Menkes, C.: Modelling $\mathrm{N}_{2}$ fixation related to Trichodesmium sp.: driving processes and impacts on primary production in the tropical Pacific Ocean, Biogeosciences, 15, 4333-4352, https://doi.org/10.5194/bg-154333-2018, 2018.

Ferreira, A., Stramski, D., Garcia, C. A. E., Garcia, V. M. T., Ciotti, A. M., and Mendes, C. R. B.: Variability in light absorption and scattering of phytoplankton in Patagonian waters: Role of community size structure and pigment composition, J. Geophys. Res.-Oceans, 118, 698-714, 2013.

Gordon, H. R.: Normalized water-leaving radiance: Revisiting the influence of surface roughness, Appl. Opt., 44, 241-248, https://doi.org/10.1364/AO.44.000241, 2005.

Gower, J., King, S., and Young, E.: Global remote sensing of Trichodesmium, Int. J. Remote Sens., 35, 5459-5466, 2014.

Grob, C., Ulloa, O., Claustre, H., Huot, Y., Alarcón, G., and Marie, D.: Contribution of picoplankton to the total particulate organic carbon concentration in the eastern South Pacific, Biogeosciences, 4, 837-852, https://doi.org/10.5194/bg-4-8372007, 2007.

Guidi, L., Calil, P. H. R., Duhamel, S., Björkman, K. M., Doney, S. C., Jackson, G. A., Li, B., Church, M. J., Tozzi, S., Kolber, Z. S., Richards, K.J., Fong, A. A., Letelier, R. M., Gorsky, G., Stemmann, L., and Karl, D. M.: Does eddy-eddy interaction control surface phytoplankton distribution and carbon export in the North Pacific Subtropical Gyre, J. Geophys. Res., 117, G02024, https://doi.org/10.1029/2012JG001984, 2012.

Hu, C., Cannizzaro, J., Carder, K. L., Muller-Karger, F. E., and Hardy, R.: Remote detection of Trichodesmium blooms in optically complex coastal waters: Examples with MODIS fullspectral data, Remote Sens. Environ., 114, 2048-2058, 2010.

Huot, Y., Morel, A., Twardowski, M. S., Stramski, D., and Reynolds, R. A.: Particle optical backscattering along a chlorophyll gradient in the upper layer of the eastern South Pacific Ocean, Biogeosciences, 5, 495-507, https://doi.org/10.5194/bg5-495-2008, 2008.

Kirk, T. O.: Light and Photosynthesis in Aquatic Ecosystems, Cambridge University Press, Nature, 509 pp., 1994.

Lantoine, F. and Neveux, J.: Spatial and seasonal variations in abundance and spectral characteristics of phycoerythrins in the Tropical Northeastern Atlantic Ocean, Deep-Sea Res Pt. I, 44, 223 246, 1997. 
Laurion, I., Blouin, F., and Roy, S.: The quantitative filter technique for measuring phytoplankton absorption: Interference by MAAs in the UV waveband, Limnol. Oceanogr.-Meth., 1, 1-9, https://doi.org/10.4319/lom.2003.1.1, 2003.

Laviale, M. and Neveux, J.: Relationships between pigment ratios and growth irradiance in 11 marine phytoplankton species, Mar. Ecol. Prog. Ser., 425, 63-77, 2011.

Le Bouteiller, A., Blanchot, J., and Rodier, M.: Size distribution patterns of phytoplankton in the western Pacific: towards a generalization for the tropical open ocean, Deep-Sea Res. Part A, 39, 805-823, 1992.

Loisel H., Meriaux, X., Berthon, J. F., and Poteau, A.: Investigation of the optical backscattering to scattering ratio of marine particles in relation to their biogeochemical composition in the eastern English Channel and southern North Sea, Limnol. Oceanogr., 2, 739-752, 2007.

Martias, C., Tedetti, M., Lantoine, F., Jamet, L., and Dupouy, C.: Characterization and sources of colored dissolved organic matter in a coral reef ecosystem subject to ultramafic erosion pressure (New Caledonia, Southwest Pacific), Sci. Total Environ., 616617, 438-452, https://doi.org/10.1016/j.scitotenv.2017.10.261, 2018.

Martinez-Vicente, V., Dall'Olmo, G., Tarran, G. A., Boss, E. B., and Sathyendranath, S.: Optical backscattering is correlated with phytoplankton carbon across the Atlantic Ocean, Geophys. Res. Lett., 40, 1-5, 2013.

McKinna, L. I. W., Furnas, M. J., and Ridd, P. V.: A simple, binary classification algorithm for the detection of Trichodesmium spp. within the Great Barrier Reef using MODIS imagery, Limnol. Oceanogr.-Meth., 9, 50-66, 2011.

McKinna, L. I. W.: Three decades of ocean-color remote-sensing Trichodesmium spp. in the World's oceans: a review, Prog. Oceanogr., 131, 177-199, 2015.

Mitchell, G.: Algorithms for determining the absorption coefficient of aquatic particulates using the quantitative filter technique (QFT), in: Ocean Optics 10, edited by: Spinrad, R., SPIE, Bellingham, WA, 136-147, 1990.

Mobley, C. D.: Light and Water: Radiative Transfer in Natural Waters, Academic Press, San Diego, 1994.

Morel A. and Maritorena, S.: Bio-optical properties of oceanic waters: A reappraisal, J. Geophys. Res., 106, 7163-7180, 2001.

Morel A., Gentili, B., Claustre, H., Babin, M., Bricaud, A., Ras, J., and Tieche, F.: Optical properties of the "clearest" natural waters, Limnol. Oceanogr., 52, 217-229, 2007.

Moutin, T., Doglioli, A. M., de Verneil, A., and Bonnet, S.: Preface: The Oligotrophy to the UlTra-oligotrophy PACific Experiment (OUTPACE cruise, 18 February to 3 April 2015), Biogeosciences, 14, 3207-3220, https://doi.org/10.5194/bg-143207-2017, 2017.

Neveux, J., Lantoine, F., Vaulot, D., Marie, D., and Blanchot, J.: Phycoerythrins in the southern tropical and equatorial Pacific Ocean: evidence for new cyanobacterial types, J. Geophys. Res., 104, 3311-3321, 1999.

Neveux, J., Tenorio, M. M. B., Dupouy, C., and Villareal, T.: Spectral diversity of phycoerythrins and diazotrophs abundance in tropical South Pacific, Limnol. Oceanogr., 51, 1689-1698, 2006.

Neveux, J., Lefebvre, J.-P., Le Gendre, R., Dupouy, C., Gallois, F., Courties, C., Gérard, P., Ouillon, S., and Fernandez, J. M.: Phyto- plankton dynamics in New-Caledonian lagoon during a southeast trade winds event, J. Mar. Sys., 82, 230-244, 2010.

Olson, E. M., McGillicuddy, D. J., Dyhrman, S. T., Waterbury, J. B., Davis, C. S., and Solow, A. R.: The depth-distribution of nitrogen fixation by Trichodesmium spp. colonies in the tropicalsubtropical North Atlantic, Deep-Sea Res. Pt. I, 104, 72-91, 2015.

Picheral, M., Guidi, L., Stemmann, L., Karl, D. M., Iddaoud, G. and Gorsky, G.: The Underwater Vision Profiler 5: An advanced instrument for high spatial resolution studies of particle size spectra and zooplankton, Limnol. Oceanogr.-Meth., 8, 462-473, 2010.

Ras, J., Claustre, H., and Uitz, J.: Spatial variability of phytoplankton pigment distributions in the Subtropical South Pacific Ocean: comparison between in situ and predicted data, Biogeosciences, 5, 353-369, https://doi.org/10.5194/bg-5-353-2008, 2008.

Rousselet, L., de Verneil, A., Doglioli, A. M., Petrenko, A. A., Duhamel, S., Maes, C., and Blanke, B.: Large- to submesoscale surface circulation and its implications on biogeochemical/biological horizontal distributions during the OUTPACE cruise (southwest Pacific), Biogeosciences, 15, 24112431, https://doi.org/10.5194/bg-15-2411-2018, 2018.

Rousset, G., De Boissieu, F., Menkes, C. E., Lefèvre, J., Frouin, R., Rodier, M., Ridoux, V., Laran, S., Bonnet, S., and Dupouy, C.: Remote Sensing of Trichodesmium spp. mats in the Western Tropical South Pacific, Biogeosciences Discuss., https://doi.org/10.5194/bg-2017-571, in review, 2018.

Sempéré, R., Para, J., Tedetti, M., Charrière, B., and Mallet, M.: Variability of Solar Radiation and CDOM in Surface Coastal Waters of the Northwestern Mediterranean Sea, J. Photoch. Photobio. A, 91, 851-861, 2015.

Shiozaki, T., Kodama, T., and Furuya, K.: Large-scale impact of the island mass effect through nitrogen fixation in the western South Pacific Ocean, Geophys. Res. Lett., 41, 2907-2913, https://doi.org/10.1002/2014GL05983, 2014.

Slade, W. H. and Boss, E.: Spectral attenuation and backscattering as indicators of average particle size, Appl. Opt., 54, 7264-7277, 2015.

Steinberg, D. K., Norman, B. Nelson, N. B. , Carlson, C. A., and Prusak, A. C.: Production of chromophoric dissolved organic matter (CDOM) in the open ocean by zooplankton and the colonial cyanobacterium https://doi.org/Trichodesmium spp. Mar. Ecol. Prog. Ser., 267, 45-56, https://doi.org/10.3354/meps267045, 2004.

Stenegren, M., Caputo, A., Berg, C., Bonnet, S., and Foster, R. A.: Distribution and drivers of symbiotic and free-living diazotrophic cyanobacteria in the western tropical South Pacific, Biogeosciences, 15, 1559-1578, https://doi.org/10.5194/bg-151559-2018, 2018.

Subramaniam, A., Carpenter, E. J., Karentz, D., and Falkowski, P. G.: Bio-optical properties of the marine diazotrophic cyanobacteria Trichodesmium spp. I - Absorption and photosynthetic action spectra, Limnol. Oceanogr., 44, 608-617, 1999a.

Subramaniam, A., Carpenter, E. J., and Falkowski, P. G.: Optical properties of the marine diazotrophic cyanobacteria Trichodesmium spp. II - A reflectance model for remote-sensing, Limnol. Oceanogr., 44, 618-627, 1999b. 
Subramaniam, A., Brown, C. W., Hood, R. R., Carpenter, E. J., and Capone, D. G.: Detecting Trichodesmium blooms in SeaWiFS imagery, Deep-Sea Res. Pt. I, 49, 107-121, 2002.

Stramski, D., Reynolds, R. A., Babin, M., Kaczmarek, S., Lewis, M. R., Röttgers, R., Sciandra, A., Stramska, M., Twardowski, M. S., Franz, B. A., and Claustre, H.: Relationships between the surface concentration of particulate organic carbon and optical properties in the eastern South Pacific and eastern Atlantic Oceans, Biogeosciences, 5, 171-201, https://doi.org/10.5194/bg5-171-2008, 2008.

Tedetti, M., Sempéré, R., Vasilkov, A., Charrière, B., Nérini, D., Miller, W., Kawamura, K., and Raimbault, P.: High penetration of ultraviolet radiation in the south east Pacific waters, Geophys. Res. Lett., 34, L12610, https://doi.org/10.1029/2007GL029823, 2007.

Tedetti, M., Charrière, B., Bricaud, A., Para, J., Raimbault, P., and Sempéré, R.: Distribution of normalized water leaving radiances at $\mathrm{UV}$ and visible wave bands in relation with chlorophyll a and colored detrital matter content in the southeast Pacific, J. Geophys. Res., 115, C02010, https://doi.org/10.1029/2009JC005289, 2010.
Tenório, M., Dupouy, C., Rodier, M., and Neveux, J.: Trichodesmium and other Filamentous Cyanobacteria in New Caledonian waters (South West Tropical Pacific) during an El Niño Episode, Aquat. Microb. Ecol., 81, 219-241, 2018.

Uitz, J., Claustre, H., Morel, A., and Hooker, S. B.: Vertical distribution of phytoplankton communities in open ocean: An assessment based on surface chlorophyll, J. Geophys. Res., 111, C08005, https://doi.org/10.1029/2005JC003207, 2006.

Westberry, T., Subramaniam, A., and Siegel, D.: An improved bio-optical algorithm for the remote sensing of Trichodesmium spp. blooms, J. Geophys. Res., 110, C06012, https://doi.org/10.1029/2004JC002517, 2005.

Westberry, T. K. and Siegel, D. A.: Spatial and temporal distribution of Trichodesmium blooms in the world's oceans, Global Biogeochem. Cy., 20, 4016, https://doi.org/10.1029/2005GB002673, 2006.

Wyman, M.: An in vivo method for the estimation of phycoerythrin concentrations in marine cyanobacteria (Synechococcus spp.), Limnol. Oceanogr., 37, 1300-1306, 1992. 